\title{
Cold shock proteins: from cellular mechanisms to pathophysiology and disease
}

\author{
Jonathan A. LindquistiD and Peter R. Mertens
}

\begin{abstract}
Cold shock proteins are multifunctional RNA/DNA binding proteins, characterized by the presence of one or more cold shock domains. In humans, the best characterized members of this family are denoted Y-box binding proteins, such as Y-box binding protein-1 (YB-1). Biological activities range from the regulation of transcription, splicing and translation, to the orchestration of exosomal RNA content. Indeed, the secretion of YB-1 from cells via exosomes has opened the door to further potent activities. Evidence links a skewed cold shock protein expression pattern with cancer and inflammatory diseases. In this review the evidence for a causative involvement of cold shock proteins in disease development and progression is summarized. Furthermore, the potential application of cold shock proteins for diagnostics and as targets for therapy is elucidated.
\end{abstract}

\section{Background}

Imagine proteins that are conserved in both structure and function, that can be found in almost all organisms from bacteria to humans (except yeast), and have been detected in almost every cellular compartment. Add to this the ability to regulate not only their own expression, but the expression of a number of disease-associated genes, and to orchestrate multiple cellular processes, including proliferation and differentiation. Who are these jack-of-all-trades? Enter our protagonists, the cold shock proteins.

\section{Members of the cold shock protein family}

Cold shock proteins are among the most evolutionarily conserved proteins [1-3]. Their distinguishing characteristic is the presence of one or more cold shock domains (CSD), which possess nucleic acid binding properties (see Fig. 1 and Table 1). This endows these proteins with pleiotropic functions, such as the regulation of transcription, translation, and splicing $[4,5]$.

Cold shock proteins were initially identified in bacteria, where a sudden drop in temperature (from $37^{\circ} \mathrm{C}$ to $10^{\circ} \mathrm{C}$ ) induced a 200 -fold increase in cold shock protein A

\footnotetext{
* Correspondence: Peter.Mertens@med.ovgu.de

Clinic for Nephrology and Hypertension, Diabetology and Endocrinology,

Otto-von-Guericke University Magdeburg, Leipziger Strasse 44, 39120

Magdeburg, Germany
}

(CspA) expression within minutes, which was independent of transcriptional activity $[3,6]$. This rapid inducibility is conserved amongst species [7]. A recent study revisited the original observation using genome-wide methods to analyze the global changes occurring in bacteria during the cold shock response [8]. The authors identified RNase $\mathrm{R}$ and CspA to be the major players. RNase $\mathrm{R}$ appears to be responsible for degrading misfolded RNAs, while CspA melts double-stranded RNAs to enable translation.

In humans, the predominant group of cold shock domain proteins is denoted the Y-box protein family. The prototypic member is Y-box binding protein-1 (YB-1), also known as DNA binding protein $\mathrm{B}$ (DbpB), encoded by the gene $Y B X 1$. Two additional family members exist, DNA binding protein $\mathrm{A}(\mathrm{DbpA})$ and $\mathrm{C}(\mathrm{DbpC})$, which are encoded by the genes $Y B X 3$ and $Y B X 2$, respectively.

Whereas $Y b x 2$ expression is restricted to germ cells [9], $Y b x 1$ and $Y b x 3$ are ubiquitously expressed during development. However, following birth the expression of $Y b \times 3$ (DbpA) is down-regulated in most tissues, the exceptions being heart, skeletal muscle, blood vessels, and testis $[10,11]$. In humans, two isoforms of DbpA are reported (DbpA_a and DbpA_b), which differ by an alternatively spliced exon that encodes the 69 amino acid long unique domain located adjacent to the CSD $[12,13]$. 


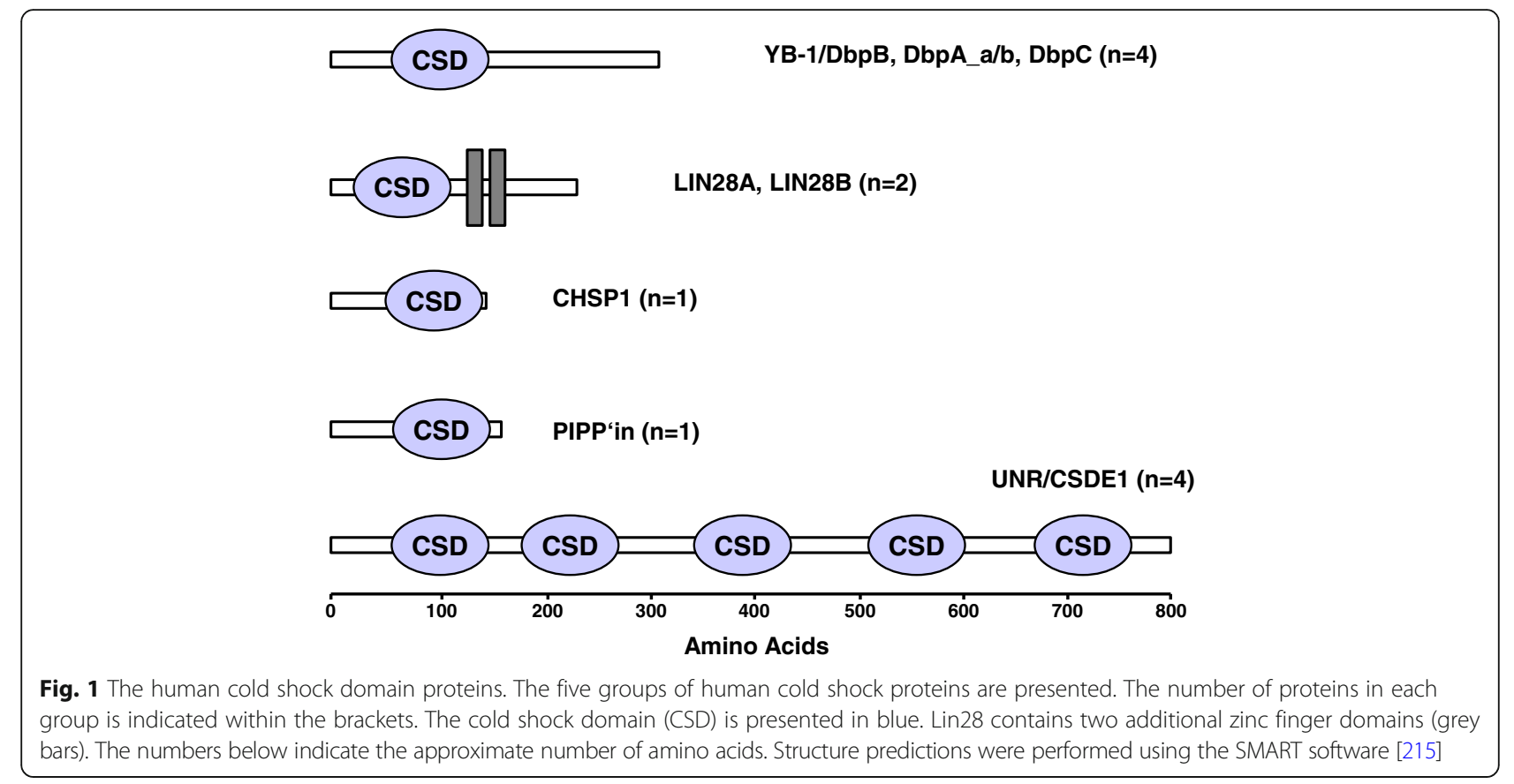

The Ybx1 knockout mouse is embryonic lethal indicating an important role during development [14]. The $Y b x 3$ knockout is viable, however the $Y b x 1 / Y b x 3$ double knockout shows a more severe developmental phenotype indicating overlapping activities during development [15].

Another developmentally important cold shock protein expressed in humans is Lin28, which was first characterized as a developmental factor in C. elegans [16]. However, it was its potential for cellular reprogramming that brought it into the spotlight, as together with Oct3, Sox2, and Nanog, Lin28 is able to revert differentiated cells into their pluripotent state [17]. In addition to the cold shock domain, Lin28A/B are unique in that they also possess two $\mathrm{CCHC}$ type zinc fingers, which form a knuckle domain that also participates in nucleic acid binding [18]. Of particular note is the ability of Lin 28 to repress let-7 miRNAs, e.g. thereby regulating glucose metabolism $[18,19]$. let- 7 also targets Lin28 creating a double-negative feedback loop [20]. In addition to miRNAs, Lin28 also binds to mRNAs, participating in a number of ribonucleoprotein complexes, such as P-bodies and stress granules, to regulate translation [21].

A further member of the human cold shock protein family is the calcium-regulated heat-stable protein 1 (CARHSP1); a $24 \mathrm{kDa}$ protein also known as CRHSP-24. Originally identified as a substrate of the calcium/calmodulin-regulated protein phosphatase calcineurin [22], CARHSP1 is a paralog of the brain-specific cold shock

Table 1 Nomenclature of the human cold shock domain proteins.

\begin{tabular}{llll}
\hline Gene & Gene synonym & Protein & Alternative names \\
\hline YBX1 & MSY1 & YB-1 & CSDB, DbpB, NSEP1, EF1A \\
YBX2 & MSY2 & DbpC & Contrin \\
YBX3 & MSY3/MSY4 & DbpA* $^{*}$ & CSDA, ZONAB, OxyR, NF-GMB, YB-2 \\
CARHSP1 & & CARHSP1 & CSDC1, CRHSP-24, CHSP1 \\
CSDC2 & PIPPin & \\
CSDE1 & UNR* & CSDD1 \\
LIN28A & & LIN28A & CSDD2
\end{tabular}

The gene names (italics), common names (bold), as well as commonly used alternative names are presented for each protein. Abbreviations are as follows: $Y$-box binding protein 1, 2, 3 (YBX1, YBX2, YBX3), mouse Y-box protein 1, 2, 3, 4 (MSY1, MSY2, MSY3, MSY4), cold shock domain A, B, C1, C2, D1, D2, E1 (CSDA-CSDE1), calcium-regulated heat stable protein 1 (CARHSP1, CHSP1), calcium regulated heat stable protein $24 \mathrm{kDa}$ (CRHSP-24), abnormal cell lineage protein 28 homolog $\mathrm{A}$, B (LIN28A), DNA binding protein A, B, C (DbpA, DbpB, DbpC), Y-box binding protein 1, 2 (YB-1, YB-2), upstream of N-Ras (UNR), nuclease sensitive element binding protein 1 (NSEP1), enhancer factor I subunit A (EF1A, rat), ZO-1-associated nucleic acid-binding protein (ZONAB), oxidative stress regulatory protein (oxyR), nuclear factor that binds the GM-CSF promoter b (NF-GMB). *Alternatively spliced protein: DbpA has two isoforms, which differ by a single domain of $\sim 70$ amino acids, whereas the UNR isoforms differ by 31 amino acids 
protein PIPPin [23]. CARHSP1 binds to and stabilizes tumor necrosis factor (TNF) mRNA within P-bodies and exosomes [24].

PIPPin expression is restricted to brain, where it binds mRNA to regulate translation [25-29]. PIPPin is found with ribonucleoprotein complexes, where it interacts with other RNA binding proteins, e.g. hnRNP A1, hnRNP K, and YB-1 [30].

The final member of this family is denoted upstream of N-RAS (UNR) [31,32]. This gene was initially identified as a regulator of $\mathrm{N}$-Ras expression [33-36]. Later it was discovered that $U N R$ encodes a protein possessing 5 cold shock domains, which undergoes alternative splicing (see Fig. 1) [37-39]; the gene was then renamed cold shock domain containing E1 (CSDE1). Like the other cold shock proteins, UNR/CSDE1 binds singlestranded DNA or RNA [37, 40, 41]. UNR works together with the polypyrimidine-tract-binding protein (PTB) to regulate translation and mRNA stability [42, 43]. The generation of Unr knockout mice demonstrated that, like $Y b x 1$, it is essential for mouse development. Further characterization demonstrated that Unr maintains the pluripotent state of embryonic stem cells $[44,45]$.

As mentioned above, cold shock proteins are components of ribonucleoprotein complexes. Two recent studies using proximity biotinylation to map components of the stress granules identified YB-1, DbpA, CSDE1, and Lin28B [46, 47]. Additionally, CHSP1 (a paralog of PIPPin) was shown to colocalize with G3BP1, an initiator of stress granule formation in human cells [24, 48, 49].

\section{Cold shock proteins: Thinking in regulatory feedforward and feedback loops}

Cells undergo stress in many ways, e.g. via interferon release in response to viral infection, the presence of lipopolysaccharide produced by bacteria, or profibrotic factors released by immune cells during inflammation. The binding of these factors to their cell surface receptors activates kinases, which phosphorylate the cold shock proteins; here we use YB-1 as an example (see Fig. 2). Upon activation, these RNA/DNA chaperones release specific mRNA, thereby enabling a rapid translational response and translocate to the nucleus to regulate gene expression. In many ways this is similar to the unfolded protein response (UPR) observed for heat shock proteins [50]. The uptake of YB-1 by cells, which is secreted as an RNA:protein complex [51,52], uniquely positions this cold shock protein to participate in cellular reprogramming by modulating the expression of numerous target genes. Many of these target genes are themselves known to regulate various aspects of disease both intra- and extracellularly (see Table 2) and can induce cold shock protein expression, e.g. PDGF-B and
TGF- $\beta$. This is envisioned to result in a feedforward amplification loop that prolongs inflammation, promotes cell proliferation and immune cell infiltration, as well as drives fibrosis, analogous to an avalanche [5, 53]. Indeed this scenario has recently been documented, supporting our goal for targeted intervention. How this circuit is terminated is unclear, however the development of cold shock protein targeting "neutralizing" antibodies presents one possibility [54]. Other potential mechanisms include the inducible proteolytic degradation of YB-1 protein, microRNA-mediated inhibition of YB-1 expression, and the induction of protein tyrosine phosphatase activity to counteract the kinase-mediated phosphorylation/activation that induces nuclear protein translocation [55-58].

\section{Cold shock proteins function in the cellular response to stress}

Components of stress granules and P-bodies have been implicated in the cellular stress response [59, 60]. Under 'normal' conditions, stress granules form when translation initiation is stalled. The RNA binding proteins G3BP1 or TIA-1 are key components of stress granule formation, as they possess the ability for self-association. Over-expression of either protein has been shown to induce stress granule formation even in the absence of stress [49, 61, 62]. Using mRNA as a scaffold, these proteins form homo- or hetero -oligomeric ribonucleoprotein complexes; self-assembly is mediated by intrinsically disordered regions (IDRs) within the RNA binding protein(s); also referred to as low complexity regions [63-68]. Several genetic mutations associated with neurodegenerative diseases have been identified that influence the self-assembly of RNA binding proteins (e.g. transactive response DNA-binding protein (TDP-43) and fused in sarcoma/translocated in liposarcoma (FUS/TLS)). Both are known to form prion-like protein aggregates; an activity attributed to their low complexity regions $[67,68]$. The more we learn about the molecular mechanisms underlying protein aggragation diseases, the greater the number of RNA binding proteins identified [69-71]. The mutations identified within these diseaseassociated proteins typically favor cytoplasmic localization, facilitate protein aggregation, or prevent granulophagy; the clearance of stress granules by autophagosomes [49, 66, 70, 72]. Recently, the expansion of intronic GGGGCC repeats within C9ORF72 was identified as a common cause of ALS/ FTD [73]. C9ORF72 interacts with endosomes and is required for normal vesicle trafficking, therefore the loss of C9ORF72 observed with G4-repeat expansion may affect granulophagy. Alternatively, the G4-repeats of C9ORF72 have been proposed to inhibit the neuroprotective effects mediated by tiRNAs binding to the cold shock domain of YB-1 [74]. 


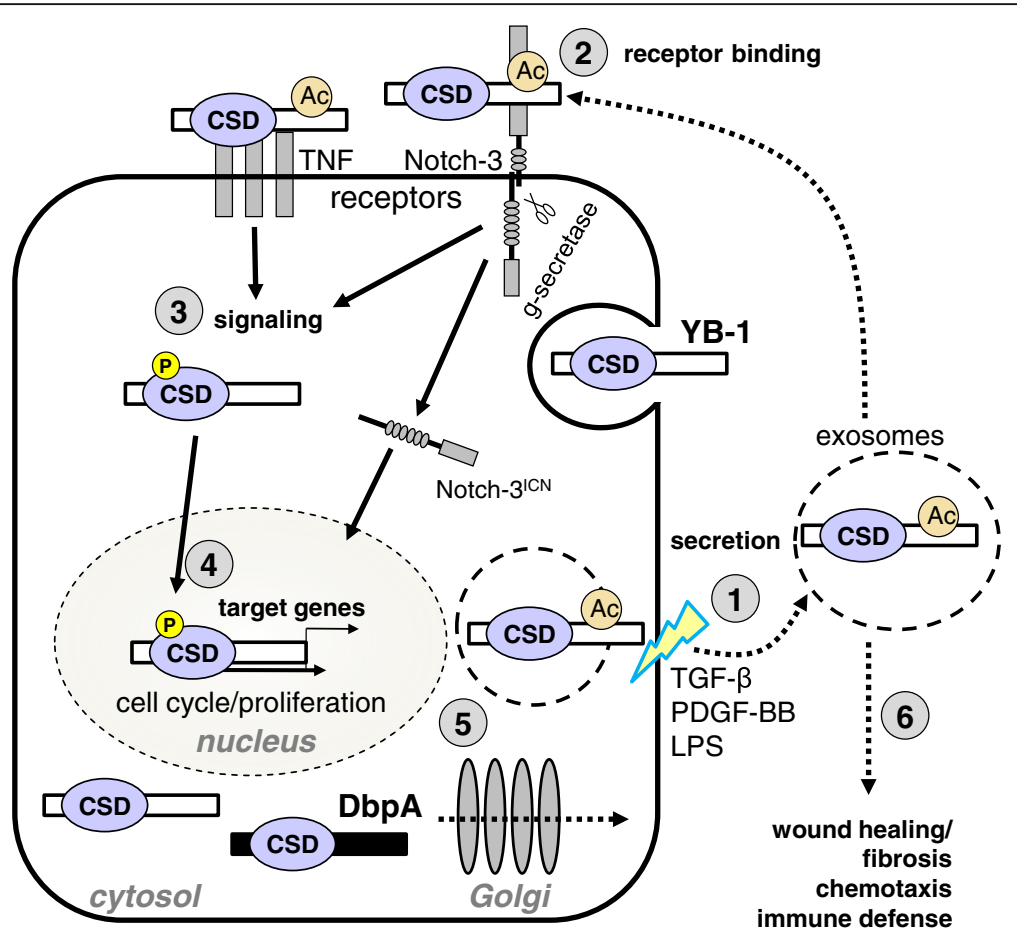

Fig. 2 Potential amplification loop for YB-1 in inflammation. (1) Extracellular stimuli (e.g. TGF- $\beta$, PDGF-B, LPS) activate cells and induce YB-1 secretion. (2) YB-1 binds to specific membrane associated receptors on the cell surface inducing intracellular signaling cascades that result in kinase activation. YB-1 can also be endocytosed. (3) Activated kinases (e.g. Akt/PKB, ERK, JAK2, RSK) phosphorylate cytoplasmic YB-1 (indicated by the yellow circle), inducing its nuclear translocation. (4) In the nucleus, YB-1 activates the transcription of target genes, as well as induces its own expression and that of DbpA. Cold shock proteins are rapidly induced in response to cell stress, due in part to the existence of preformed complexes of cold shock proteins with their cognate mRNA. (5) Activated cells may also secrete YB-1, which may then act in either an autocrine or paracrine manner. Activated cells may also secrete DbpA via the Golgi. (6) Extracellular YB-1 has mitogenic activity that promotes wound healing/fibrosis. YB-1 also contributes to the recruitment of immune cells to the site of inflammation; directly via its chemoattractant activity or indirectly via the products of its target genes, e.g. CCL5/RANTES. Extracellular activities for DbpA await elucidation. Abbreviations: acetylation (Ac); cold shock domain (CSD); DNA binding protein A (DbpA); lipopolysaccharide (LPS); phosphorylation (P); platelet-derived growth factor B homodimer (PDGF-BB); transforming growth factor beta (TGF- $\beta$ ); tumor necrosis factor (TNF); Y-box binding protein 1 (YB-1)

As a known component of stress granules, YB-1 also possesses the ability for self-assembly [75]. YB-1 has been shown to form amyloid-like fibrils, an activity attributed to its C-terminal domain, which is composed of alternating regions of positive or negatively charged amino acids that form a zipper-like structure as well as contributes to its RNA binding activity [76-81]. Interestingly, the oligomerization of YB-1 is induced by a select set of RNAs [79]. In the context of neurodegeneration, YB-1 and G3BP1 have been shown to compete with TDP-43 and FUS for mRNA binding and thereby induce the release of prion-like protein aggregates that have formed [82]. To complicate matters further, in human sarcoma YB-1 activates G3BP1 mRNA thereby controlling both the expression levels of G3BP1 and the subsequent nucleation of stress granule formation [83]. Indeed cold shock is one trigger of stress granule assembly in mammals [84]. Stress granules have been implicated in the pathophysiology for a number of neurodegenerative diseases, including
Alzheimer's, amyotrophic lateral sclerosis (ALS), frontotemporal dementia (FTD), spinocerebellar ataxia (SCA), and Huntington's disease [49, 71, 85]. Here we propose possible mechanisms where cold shock proteins may play a critical role in the pathophysiology of these diseases. When granulophagy is defective either due to an inability to degrade protein aggregates or to system overload, i.e. when the rate of production exceeds degradation, stress granules that would normally undergo autophagy become lysosomes [64]. The autophagic pathway intersects with both the classical and the unconventional pathways of protein secretion $[86,87]$. YB-1 is secreted via a non-classical pathway involving ATP-binding cassette transporters and microvesicles, as well as post-translational modification of two C-terminal lysine residues (K301/K304) [88, 89]. Non-canonical K27-linked ubiquitination of YB-1 was shown to be required for its interaction with tumor susceptibility gene 101 (TSG101), a component of multivesicular bodies (MVBs) [90]. Fusion of MVB with the plasma 
Table 2 Genes regulated by cold shock proteins in disease

\begin{tabular}{|c|c|c|c|c|c|}
\hline Protein & Disease & Target Cell & Mode of Action & Target Gene & Ref. \\
\hline \multirow[t]{19}{*}{ YB-1 } & Sepsis & $\begin{array}{l}\text { neutrophils, } \\
\text { macrophages }\end{array}$ & N.D. & $\begin{array}{l}\text { Toll-like receptor } 4 \\
\text { (TLR4) CXCL-1 }\end{array}$ & {$[123]$} \\
\hline & $\begin{array}{l}\text { T-cell activation Autoimmunity } \\
\text { Inflammation }\end{array}$ & T-helper cells & $\begin{array}{l}\text { binding and stabilization } \\
\text { of mRNA }\end{array}$ & Interleukin 2 (IL-2) & {$[129,204]$} \\
\hline & \multirow[t]{2}{*}{ Allergic asthma } & activated eosinophils & $\begin{array}{l}\text { stabilization and up-regulation of } \\
\text { mRNA transcripts }\end{array}$ & GM-CSF & [140] \\
\hline & & $\begin{array}{l}\text { embryonic lung } \\
\text { fibroblasts }\end{array}$ & suppression of gene transcription & GM-CSF & {$[205]$} \\
\hline & Chronic liver disease & $\begin{array}{l}\text { activated hepatic } \\
\text { stellate cells }\end{array}$ & $\begin{array}{l}\text { induction of expression; } \\
\text { antagonizes TGF } \beta \text { signaling }\end{array}$ & Smad7 & [153] \\
\hline & Chronic liver disease & $\begin{array}{l}\text { rat hepatoma } \\
\text { cells (FAO) }\end{array}$ & suppression of gene transcription & Mrp2 & {$[206]$} \\
\hline & Kidney transplant rejection & primary monocytes & activation of gene transcription & RANTES/CCL5 & {$[126]$} \\
\hline & Kidney transplant rejection & $\begin{array}{l}\text { differentiated } \\
\text { macrophages }\end{array}$ & suppression of gene transcription & RANTES/CCL5 & {$[126]$} \\
\hline & $\begin{array}{l}\text { Neointimal hyperplasia } \\
\text { Atherosclerosis }\end{array}$ & $\begin{array}{l}\text { vascular smooth } \\
\text { muscle cells }\end{array}$ & activation of gene transcription & RANTES/CCL5 & {$[127]$} \\
\hline & Endometriosis & $\begin{array}{l}\text { peritoneal } \\
\text { macrophages }\end{array}$ & $\begin{array}{l}\text { activation of gene transcription } \\
\text { and recruitment of inflammatory } \\
\text { cells }\end{array}$ & RANTES/CCL5* & {$[207,208]$} \\
\hline & $\begin{array}{l}\text { Chronic kidney disease } \\
\text { Interstial kidney disease }\end{array}$ & $\begin{array}{l}\text { proximal tubular } \\
\text { cells }\end{array}$ & control of translation & TGF $\beta$ & {$[132,209]$} \\
\hline & $\begin{array}{l}\text { Mesangioproliferative } \\
\text { glomerulonephritis }\end{array}$ & endothelial cells & gene transcription & PDGF-B & [111] \\
\hline & $\begin{array}{l}\text { Mesangioproliferative } \\
\text { glomerulonephritis }\end{array}$ & renal cells & gene transcription, secretion & PDGF-B & [138] \\
\hline & Tubulointerstial nephritis & $\begin{array}{l}\text { renal cells, } \\
\text { macrophages }\end{array}$ & $\begin{array}{l}\text { gene transcription, secretion, } \\
\text { differentiation, phagocytosis }\end{array}$ & $\begin{array}{l}\text { RANTES/CCL5 MCP-1/ } \\
\text { CCL2 IL-10 }\end{array}$ & {$[124,203]$} \\
\hline & Dysregulated angiogenesis & & repression of VEGF promotor & VEGF & [210] \\
\hline & $\begin{array}{l}\text { Calcineurin inhibitor mediated } \\
\text { kidney fibrosis }\end{array}$ & mesangial cells & binding and stabilization of mRNA & Collagen & [136] \\
\hline & Anti-Thy 1.1 nephritis & mesangial cells & gene transcription, secretion & Notch-3 & [54] \\
\hline & Type II diabetes & skeletal muscle & $\begin{array}{l}\text { gene transcription, signal } \\
\text { pathways }\end{array}$ & PTP1B & {$[55]$} \\
\hline & T-ALL & $\mathrm{T}$ cell & Cell cycle & Cdk6 & [181] \\
\hline CHSP1 & Inflammation Sepsis & macrophages & enhancement of mRNA stability & TNF & [24] \\
\hline \multirow[t]{3}{*}{ Dbpa } & Dysregulated angiogenesis & fibroblasts & repression of VEGF promoter & VEGF & {$[130,210]$} \\
\hline & Hepatocellular carcinoma & hepatocytes & & & {$[211-214]$} \\
\hline & $\begin{array}{l}\text { Mesangioproliferative } \\
\text { glomerulonephritis }\end{array}$ & renal cells & gene transcription, secretion & DbpA & [13] \\
\hline
\end{tabular}

For the studied cold shock domain proteins, the disease, target cell, mode of action, and target genes are listed, together with the relevant citation. In sepsis, the mode of action has not been determined (N.D.). Modified from Lindquist et al. [4].

membrane is required for the release of exosomes [91]. Since YB-1 is a component of exosomes, required for the sorting of mRNAs [51, 52, 92-94], it remains to be determined whether stress granule clearance coincides with the pathway of exosome formation and YB-1 secretion. If these pathways are indeed one in the same, does this apply to both cytoplasmic and nuclear stress granules? Should this hypothesis hold true for YB-1, it will be of interest to see whether it also applies to other cold shock proteins, such as DbpA or CSDE1, that have already been identified as components of both stress granules and exosomes $[95,96]$.

\section{Cold shock proteins in disease}

The decisive data for a causal relationship between cold shock proteins and disease comes from cancer. The role 
of YB-1 as an oncoprotein was secured when it was demonstrated that $100 \%$ of YB-1 transgenic mice overexpressing the protein developed invasive tumors [97]. YB-1 and DbpA expression is upregulated in cancer and nuclear localization indicates a poor prognosis [57, 98]. In the nucleus, cold shock proteins bind to single- and double-stranded DNA and serve as transcriptional regulators. In tumors, nuclear YB-1 correlates with enhanced expression of the multidrug resistance protein 1 (MDR1) [99-105]. Cells in which YB-1 expression has been ablated using small inhibitory RNA fail to proliferate and were recently shown to prevent tumor growth by disrupting angiogenesis [106].

YB-1 can also be secreted [88]. Acetylation and ubiquitination of YB-1 have both been shown to play roles in regulating secretion as well as intracellular stability [58, 90, 107, 108]. YB-1 can be proteolytically cleaved and extracellular YB-1, and/or fragments thereof, is found in the serum of patients, binds to cell surface receptors, and exerts extracellular activities, e.g. enhancing proliferation and induces migration of immune cells [56, 89, 109-114].

Serum YB-1 levels are increased in cancer patients and the occurrence of extracellular YB-1 or its fragments may serve as a useful marker for cancer, as 80\% of patients tested positive for the YB-1/p18 fragment, whereas inflammatory diseases did not correlate with positive results $[98,112-115]$.

Lin28 reactivation is also found in a number of cancers, where Lin 28 appears to contribute to the formation of cancer stem cells [18]. The role of Lin28 in cancer has been extensively reviewed elsewhere [116]. Similar to Lin28, $U n r$ also regulates the differentiation state of cells [44]. Due to its ability to regulate the expression of several proto-oncogenes, UNR has also been investigated in cancer [117-119]. In prostate cancer, a novel regulatory activity of HEPSIN on UNR was identified [120, 121]. UNR expression levels have also been demonstrated as a prognostic biomarker for survival in pancreatic ductal adenocarcinoma [122].

For inflammatory and fibrotic diseases, the data for the role of cold shock proteins appears more associative. The initial data came from animal studies on $Y b x 1$ heterozygous mice, which express only half the amount of YB-1 compared to wild type. The induction of disease in experimental models such as sterile sepsis or unilateral ureter obstruction identified non-redundant roles for YB-1 in the development of inflammation and fibrosis [123, 124]. These activities are mediated in part by YB-1-dependent gene regulation of pro-inflammatory factors (PDGF-B, VEGF, IL-2, GM-CSF, EGF, TGF- $\beta$, CCL2, CCL5, and CXCR4) [111, 125-134] as well as fibrosis-related genes (MMP2, Col1a1, and Col2a1) (see Table 2) [135-137]. In mesangioproliferative glomerulonephritis, cold shock protein expression is clearly induced; an effect mediated by PDGF-B, and regulates mesangial cell proliferation [13, 138]. In atherosclerosis, YB-1 contributes to neointima formation by modulating CCL5 expression [126, 127, 139]. In asthma, YB-1 promotes eosinophil survival by stabilizing granulocyte macrophage-colony-stimulating factor mRNA [140, 141]. Successful approaches to ameliorate diseases by targeting YB-1 activities have been demonstrated [124, 142-146].

\section{From molecules to intervention strategies: Rationale for cold shock protein targeting}

We propose that cold shock proteins represent verifiable targets for therapeutic intervention and envision strategies aimed at targeting cold shock proteins directly or targeting cold shock protein-dependent mechanisms. This goal is supported by the following observations that link the prototypic cold shock protein YB-1 with other key molecule activities. For the latter, intervention strategies have already proven to be successful.

1. YB-1 regulates NF- $\mathrm{kB}$ activation. In the absence of $\mathrm{YB}-1, \mathrm{NF}-\mathrm{\kappa} B$ activation is defective $[147,148]$.

2. YB-1 regulates IL-2 production. CD28 costimulation is required for $\mathrm{T}$ cell activation and the induction of autocrine IL-2 production. CD28 signals stabilize IL-2 mRNA. YB-1 is one of the essential RNA binding proteins that mediate this activity [129].

3. YB-1 interacts with p53. Nuclear YB-1 regulates p53 function by inhibiting its ability to induce apoptosis, however it does not influence p53's regulation of cell cycle [149-151].

4. YB-1 and TGF- $\beta$ counter-regulate one another. It was recently demonstrated that TGF- $\beta$ induces miR-216a, which suppresses YB-1 expression. YB-1 suppresses Tsc22, which serves as an enhancer for Col1a2 expression [152]. Additionally, we have shown that YB-1 mediates the anti-fibrotic effect of interferon-gamma, directly competes for Smad3 binding to $\mathrm{p} 300 / \mathrm{CBP}$ [153].

Molecular pathways are not per se pathological, but rather part of regulatory networks. A prolonged or permanent dysregulation results in diseases, especially those of an inflammatory or malignant nature. Developing targeted therapies requires insight into the molecular pathways of underlying diseases, as pivotal cell decisions are dependent on the "activation" of key molecules. Examples of such molecules are provided in the following.

NF-kB; diseases: Cancer, inflammatory, and autoimmune Nuclear factor binding near the kappa-light-chain gene in $\mathrm{B}$ cells $(\mathrm{NF}-\mathrm{\kappa} \mathrm{B})$ are a family of inducible transcription 
factors that control inflammatory gene expression [154157]. In many cancers, NF- $\mathrm{KB}$ is constitutively active and localized to the nucleus. Therefore many anti-tumor therapies seek to block NF- $k B$ activity as a means to inhibit tumor growth or to sensitize tumor cells to conventional therapies, such as chemotherapy. The extensive involvement of NF-kB in inflammation and disease has also established it as a therapeutic target. Indeed, many common synthetic (e.g., aspirin, ibuprofen, glucocorticoids) and traditional medicines (e.g., green tea, curcumin) target the NF- $\mathrm{kB}$ pathway. To date, over 800 compounds have been shown to inhibit NF- $\mathrm{KB}$ signaling (such as anatabine, disulfiram, dithiocarbamates, olmesartan). Many natural products (including anti-oxidants) that have been promoted to have anti-cancer and anti-inflammatory activity have also been shown to inhibit NF-kB.

\section{IL-2; diseases: Autoimmune and organ transplantation; cancer, viral infection, and vaccination}

Interleukin-2 (IL-2) is essential for lymphocyte survival, differentiation, and proliferation [158-161]. Therefore, many immunosuppressive drugs (such as corticosteroids, cyclosporine A, and tacrolimus) used to treat autoimmune diseases or suppress graft rejection work by inhibiting the production of IL-2 by antigen-activated T cells. Sirolimus blocks intracellular IL-2R signaling, thereby preventing the clonal expansion of activated $\mathrm{T}$ cells. The extracellular effects of IL-2 are abrogated by monoclonal antibody application. The use of antibody induction after kidney transplantation has increased to $60 \%$ in the past decade and roughly one half of the induction agent used is anti-interleukin-2 receptor alpha antibody (IL-2RA, i.e. basiliximab or daclizumab). In combination with calcineurin inhibitors, IL-2RAs have been shown to reduce the incidence of acute rejection without increasing risks of infections or malignancies in kidney transplantation.

Recombinant IL-2 has been approved for the treatment of cancers (malignant melanoma, renal cell cancer) and has been tested in clinical trials for the treatment of chronic viral infections, and as an adjuvant for vaccines.

\section{p53; disease: Cancer}

Tumor protein p53 (p53) is a tumor suppressor and the most frequently mutated gene in human cancers [162165]. People who possess only one functional copy of the p53 gene have a higher incidence of tumor development. The p53 gene can also be damaged by chemical mutagenesis or radiation, as well as p53 protein inactivated by viruses (e.g. human papillomavirus). p53 itself does not bind to DNA, but rather exerts its influence via its complex interactions with transcription factors and regulators. p53 mutants are associated with changes in chromatin structure, leading to genetic instability and alterations in cell cycle regulation as well as cellular metabolism. $\mathrm{Mu}-$ tant p53 has been shown to act downstream of the TNF receptor to prolong and enhance NF- $\mathrm{kB}$ activation thereby driving tumor-promoting inflammation and enhancing chemokine secretion. The p53 pathway inhibitors nutlin and PRIMA- 1 reactivate p53 function, enhancing its antiproliferative activity and thereby sensitizing cancer cells to apoptosis [166].

\section{TGF- $\beta$; diseases: Organ fibrosis, cancer, immune suppression}

Transforming growth factor- $\beta$ (TGF- $\beta$ ) promotes fibroblast proliferation, differentiation, and survival. In addition to inducing cytokine secretion, TGF- $\beta$ upregulates the synthesis of collagens and extracellular matrix, making it a therapeutic target in fibrotic diseases [167]. TGF- $\beta$ also induces the epithelial-mesenchymal xtransition (EMT); an important step in tumor progression, thus making it a target for anti-cancer therapy [168]. Strategies to target TGF- $\beta$ include neutralizing monoclonal antibodies targeting TGF- $\beta$, monoclonal antibodies targeting the integrin $\alpha_{\mathrm{v}} \beta_{6}$ are aimed at preventing the activation of latent TGF- $\beta$, and small molecules targeting TGF- $\beta$ receptor activity. Additionally, some commonly used drugs, e.g. the kinase inhibitor imatinib mesylate, appear to also block TGF- $\beta$ activities and abrogate fibrotic responses $[169,170]$. However, inhibiting TGF- $\beta$ can also have unwanted effects, such as enhanced immune cell activation (due to the loss of TGF- $\beta$-mediated inhibition), hindering implantation during pregnancy, and impaired wound healing (within a normal response to injury).

\section{Outlook}

Diagnostics and therapy with interventions targeting cold shock proteins

Cold shock protein expression is a suitable biomarker for diverse disease activities [112-114]. The presence of extracellular cold shock proteins, and/or fragments thereof, may serve diagnostic purposes. Beyond their diagnostic potential, we envision that therapeutic interventions targeting cold shock proteins may reduce disease burden, as YB-1 is expected to target pathways distinct from those targeted by current therapies. Therefore, we anticipate at least in some cases synergistic activity with existing therapies.

At present cold shock protein research is on the verge of entering clinical trials in different fields, especially for advanced cancer disease (ongoing trials adopt a vaccination strategy against YB-1 epitope in HER2negative stage III-IV breast cancer or an oncolytic virotherapy in bladder cancer). In experimental disease models intervention strategies targeting YB-1 reduced inflammation and organ fibrosis [124, 142, 143, 171]. 
HSc025 was identified in a natural products screen for compounds that suppressed collagen gene expression, i.e. fibrosis [172]. HSc025 promotes nuclear translocation of YB-1, which acts as a suppressor of the gene COL1A2 (collagen type I alpha 2) thereby reducing fibrosis [137, 142, 153, 171, 173-175].

Another compound is the natural product fisetin (3,7,3', $4^{\prime}$-tetrahydroxyflavone); a polyphenolic compound found in plants, also called a flavonoid, that demonstrated anti-cancer as well as anti-inflamatory activity $[176,177]$. Fisetin blocks the Akt-mediated phosphorylation of $\mathrm{Ser}^{102}$ within the CSD [144, 178]. However, an inhibition of p70S6K, a member of the ribosomal S6 kinase (RSK) family, has also been reported [179]. Molecular modeling proposed that fisetin binds to the CSD of YB-1; if such binding prevents YB-1 from being phosphorylated then this proposal would unify these reports, as both kinases phosphorylate $\operatorname{Ser}^{102}[144,180,181]$. Regardless of the mechanism of action, fisetin prevents the nuclear translocation of YB-1 by preventing phosphorylation of the CSD.

\section{Developing topics in the cold shock protein field}

Pro-inflammatory factors, like TNF, activate NF-kB, which induces miR-155 expression. Increased miR-155 suppresses CARHSP1, which stabilizes TNF mRNA; thus, this negative feedback loop relieves chronic inflammation and was shown to play a protective role during atherosclerosis [182].

The modulation of tumor necrosis factor receptor signaling by extracellular cold shock proteins is relevant to a number of diseases, including preeclampsia, diabetic nephropathy, systemic lupus erythematosus, liver fibrosis, and infectious diseases where TNF plays a central role in disease pathology [183]. Additionally, TNF promotes expansion of JAK2V617F positive cells in myeloproliferative neoplasms [184]. Extracellular cold shock proteins are also topics of interest, as is their potential role in fetal-maternal communication during implantation.

Receptor Notch-3 is a developmental receptor that plays an important role in stem cell maintenance as well as in cell differentiation. Known roles include the development thymocytes as well as hepatocellular carcinoma. Strong expression is also found in the placenta and uterus suggesting an important role in pregnancy. Extracellular YB-1 serves as a noncanonical ligand for receptor Notch-3 and therefore its ability to modulate receptor Notch-3 signaling is of relevance [88, 89]. Progranulin has recently been demonstrated as a Notch ligand [185] and therefore YB-1/progranulin may also modulate Notch signaling, which may be of relevance in a number of diseases, e.g. diabetic nephropathy, systemic lupus erythematosus, liver fibrosis, and infectious disease.
The participation of extracellular cold shock proteins in inter-organ communication is another important emerging idea (i.e. endocrine activity). Liverkidney interactions have recently been described for nonalcoholic fatty liver disease (NAFLD) [186]. Here, the liver is an important source of pro-inflammatory cytokines, which modulate inflammation and renal injury [187, 188]. Chronic kidney disease induces intestinal dysbiosis, which contributes to systemic inflammation (via the production of uremic toxins) thereby promoting NAFLD. Inflammation also drives renal fibrosis, which further reduces kidney function, in so doing enhances the levels of uremic toxins within the blood, creating a self-perpetuating multiorgan disease [189]. Several pro-inflammatory cytokines as well as bacterial toxins, e.g. lipopolysaccharide, induce cold shock protein secretion, which binds to TNF receptors and receptor Notch-3 [89]. Therefore we believe that extracellular cold shock proteins are intimately involved in this cycle.

Finally, evidence is emerging that cold shock proteins may regulate the formation of protein aggregates in neurodegenerative diseases [82]. The role of exosomes in the spreading of neurodegenerative and prion diseases is well documented [190-192]. However, it remains to be determined whether stress granules do indeed serve as precursors for exosomes and if so, to what extent they contribute to the spread of neurodegenerative diseases versus the detoxification of cells by removing protein aggregates or perhaps both. Additionally, it remains to be shown whether the targeting of cold shock proteins in this context might be of therapeutic benefit.

Since many components of stress granules and Pbodies are also targets of autoantibodies, the question remains as to whether this pathway contributes to the generation of autoantibodies against YB-1 [193-196]. Certainly the RNA:protein complexes described as "beads on a string" possess the essential elements (i.e. multiple repeating epitopes) required for the successful activation of B-cells [80, 197].

\section{Post-translational modifications of cold shock proteins}

The number of post-translational modifications identified within cold shock proteins is continually growing [198]. A recent paper described O-GlcNAcylation of YB-1; a post-translational modification linking nutrient and stress sensing to transcriptional and translational regulation $[199,200]$. This novel modification was shown to contribute to the oncogenic potential of YB-1 in hepatocellular carcinoma (HCC) and appears to exert its activity within the nucleus, since it also requires phosphorylation of Ser102 within the CSD. O-GlcNAcylation is mediated by the enzyme O-GlcNAc transferase (OGT), which is 
known to promote liver cancer as well as a number of diseases, such as diabetes and neurodegeneration [200, 201]. Since O-GlcNAcylation of NF-kB potentiates its acetylation [202], it will be interesting to see whether a similar effect is also found for the acetylation of YB-1. As you see from this example, there is still much work to be done in linking a particular post-translational modification to specific protein activities. To extrapolate this idea further, it remains to be seen whether there are cell-specific modifications or activities of the cold shock proteins and whether these apply to particular compartments within the cell (e.g. nucleus, mitochondria, exosomes, etc.). Here, it is anticipated that CRISPR/Cas technology will help in creating and characterizing cell lines with specific point mutations targeting a particular modified amino acid. However, there is still much work to be done in identifying and characterizing cell-specific activities of the cold shock proteins. Our recent study demonstrating cell-specific activities of YB-1 in monocytes and macrophages is likely merely the tip of the iceberg [203]. There are still numerous organs, cell types, and cell subsets (e.g. Th1 versus Th2 cells) awaiting characterization. Therefore strategies aimed at deleting $Y b x 1$ in specific tissues and/or cell types must consider possible developmental effects when characterizing the phenotypes of such cells. Add to this the presence of cold shock proteins within exosomes and thus their extracellular activities and we have a long road ahead to fully understand the complex behavior and activities of these fascinating proteins in both health and disease. Here, the application of high-throughput omics technologies will be essential to keep track of the changes going on within such cells on both the transcriptional as well as translational levels.

\section{Abbreviations \\ Ac: Acetylation; CARHSP1: Calcium-regulated heat-stable protein 1; CBP: CREB-binding protein; CCL2: Chemokine (C-C motif) ligand 2; CCL5: Chemokine (C-C motif) ligand 5; CRHSP-24: Calcium-regulated heat- stable protein of $24 \mathrm{kDa}$; CSD: Cold shock domain; CspA: Cold shock protein A; CXCR4: C-X-C motif chemokine receptor 4; DbpA: DNA binding protein A; DbpB: DNA binding protein B; DbpC: DNA binding protein C; EGF: Epidermal growth factor; EMT: Epithelial-mesenchymal transition; FUS/TLS: Fused in sarcoma/translocated in liposarcoma; GM-CSF: Granulocyte-macrophage colony-stimulating factor; HER2: Human epidermal growth factor receptor 2; hnRNP: Heterogeneous nuclear ribonucleoprotein; IL-2: Interleukin-2; IL- 2RA: Interleukin-2 receptor alpha; JAK: Janus kinase; LPS: Lipopolysaccharide; MDR1: Multidrug resistance protein 1; mRNA: Messenger RNA; NAFLD: Nonalcoholic fatty liver disease; NF-KB: Nuclear factor binding near the kappa-light-chain gene in B cells; PDGF-B: Platelet-derived growth factor subunit B; TDP-43: transactive response DNA-binding protein; TGF- $\beta$ : Transforming growth factor beta; TNF: Tumor necrosis factor; UNR: Upstream of N-Ras; UPR: Unfolded protein response; VEGF: Vascular endothelial growth factor; YB-1: Y-box binding protein-1}

\section{Acknowledgements}

The authors would like to thank Dr. Sabine Brandt for helpful discussion.

\section{Funding}

This work was supported by the Deutsche Forschungsgemeinschaft (DFG): SFB 854, project A01, grants ME-1365/7-2 and ME-1365/9-1 to PRM, and LI1031/4-1 to JAL.
Authors' contributions

JAL and PRM wrote and edited the manuscript. Both authors read and approved the final manuscript.

Ethics approval and consent to participate Not applicable.

\section{Consent for publication}

Not applicable.

\section{Competing interests}

The authors declare that they have no competing interests

\section{Publisher's Note}

Springer Nature remains neutral with regard to jurisdictional claims in published maps and institutional affiliations.

Received: 6 March 2018 Accepted: 13 September 2018

Published online: 26 September 2018

\section{References}

1. Wolffe AP, Tafuri S, Ranjan M, Familari M. The Y-box factors: a family of nucleic acid binding proteins conserved from Escherichia coli to man. New Biol. 1992:4(4):290-8

2. Wolffe AP. Structural and functional properties of the evolutionarily ancient Y-box family of nucleic acid binding proteins. BioEssays. 1994:16(4):245-51.

3. Jones PG, Inouye M. The cold-shock response--a hot topic. Mol Microbiol. 1994:11(5):811-8.

4. Lindquist JA, Brandt S, Bernhardt A, Zhu C, Mertens PR. The role of cold shock domain proteins in inflammatory diseases. J Mol Med (Berl). 2014; 92(3):207-16.

5. Brandt S, Raffetseder U, Djudjaj S, Schreiter A, Kadereit B, Michele M, Pabst M, Zhu C, Mertens PR. Cold shock Y-box protein-1 participates in signaling circuits with auto-regulatory activities. Eur J Cell Biol. 2012;91(6-7):464-71.

6. Gottesman S. Chilled in translation: adapting to bacterial climate change. Mol Cell. 2018;70(2):193-4.

7. Graumann PL, Marahiel MA. A superfamily of proteins that contain the coldshock domain. Trends Biochem Sci. 1998;23(8):286-90.

8. Zhang Y, Burkhardt DH, Rouskin S, Li GW, Weissman JS, Gross CA. A stress response that monitors and regulates mRNA structure is central to cold shock adaptation. Mol Cell. 2018;70(2):274-86 e277.

9. Snyder E, Soundararajan R, Sharma M, Dearth A, Smith B, Braun RE. Compound heterozygosity for $Y$ box proteins causes sterility due to loss of translational repression. PLoS Genet. 2015;11(12):e1005690.

10. Berghella L, De Angelis L, De Buysscher T, Mortazavi A, Biressi S, Forcales SV, Sirabella D, Cossu G, Wold BJ. A highly conserved molecular switch binds MSY-3 to regulate myogenin repression in postnatal muscle. Genes Dev. 2008:22(15):2125-38.

11. Lima WR, Parreira KS, Devuyst O, Caplanusi A, N'Kuli F, Marien B, Van Der Smissen P, Alves PM, Verroust P, Christensen El, Terzi F, Matter K, Balda MS, Pierreux CE, Courtoy PJ. ZONAB promotes proliferation and represses differentiation of proximal tubule epithelial cells. J Am Soc Nephrol. 2010; 21(3):478-88

12. Hasegawa SL, Doetsch PW, Hamilton KK, Martin AM, Okenquist SA, Lenz J, Boss JM. DNA binding properties of YB-1 and dbpA: binding to doublestranded, single-stranded, and abasic site containing DNAs. Nucleic Acids Res. 1991;19(18):4915-20

13. Zhu C, Sauter E, Schreiter A, van Roeyen CR, Ostendorf T, Floege J, Gembardt F, Hugo CP, Isermann B, Lindquist JA, Mertens PR. Cold shock proteins mediate GN with Mesangioproliferation. J Am Soc Nephrol. 2016; 27(12):3678-89.

14. Fan L, Jones SN, Padden C, Shen Q, Newburger PE. Nuclease sensitive element binding protein 1 gene disruption results in early embryonic lethality. J Cell Biochem. 2006;99(1):140-5.

15. Lu ZH, Books JT, Ley TJ. Cold shock domain family members YB-1 and MSY4 share essential functions during murine embryogenesis. Mol Cell Biol. 2006; 26(22):8410-7

16. Ambros $\mathrm{V}$. A hierarchy of regulatory genes controls a larva-to-adult developmental switch in C. elegans. Cell. 1989;57(1):49-57.

17. Yu J, Vodyanik MA, Smuga-Otto K, Antosiewicz-Bourget J, Frane JL, Tian S, Nie J, Jonsdottir GA, Ruotti V, Stewart R, Slukvin II, Thomson JA. Induced 
pluripotent stem cell lines derived from human somatic cells. Science. 2007; 318(5858):1917-20.

18. Thornton JE, Gregory RI. How does Lin28 let-7 control development and disease? Trends Cell Biol. 2012;22(9):474-82.

19. Zhu H, Shyh-Chang N, Segre AV, Shinoda G, Shah SP, Einhorn WS, Takeuchi A, Engreitz JM, Hagan JP, Kharas MG, Urbach A, Thornton JE, Triboulet R, Gregory Rl, Consortium D, Investigators M, et al. The Lin28/let-7 axis regulates glucose metabolism. Cell. 2011;147(1):81-94.

20. Rybak A, Fuchs H, Smirnova L, Brandt C, Pohl EE, Nitsch R, Wulczyn FG. A feedback loop comprising lin-28 and let-7 controls pre-let-7 maturation during neural stem-cell commitment. Nat Cell Biol. 2008; 10(8):987-93.

21. Mayr F, Heinemann U. Mechanisms of Lin28-mediated miRNA and mRNA regulation--a structural and functional perspective. Int J Mol Sci. 2013;14(8): 16532-53.

22. Groblewski GE, Yoshida M, Bragado MJ, Ernst SA, Leykam J, Williams JA. Purification and characterization of a novel physiological substrate for calcineurin in mammalian cells. J Biol Chem. 1998;273(35):22738-44.

23. Schafer C, Steffen H, Krzykowski KJ, Goke B, Groblewski GE. CRHSP-24 phosphorylation is regulated by multiple signaling pathways in pancreatic acinar cells. Am J Physiol Gastrointest Liver Physiol. 2003;285(4):G726-34.

24. Pfeiffer JR, McAvoy BL, Fecteau RE, Deleault KM, Brooks SA. CARHSP1 is required for effective tumor necrosis factor alpha mRNA stabilization and localizes to processing bodies and exosomes. Mol Cell Biol. 2011;31(2):277-86.

25. Castiglia D, Scaturro M, Nastasi T, Cestelli A, Di Liegro I. PIPPin, a putative RNA-binding protein specifically expressed in the rat brain. Biochem Biophys Res Commun. 1996;218(1):390-4.

26. Nastasi T, Scaturro M, Bellafiore M, Raimondi L, Beccari S, Cestelli A, di Liegro I. PIPPin is a brain-specific protein that contains a cold-shock domain and binds specifically to H1 degrees and H3.3 mRNAs. J Biol Chem. 1999;274(34): 24087-93.

27. Nastasi T, Muzi P, Beccari S, Bellafiore M, Dolo V, Bologna M, Cestelli A, Di Liegro I. Specific neurons of brain cortex and cerebellum are PIPPin positive. Neuroreport. 2000;11(10):2233-6.

28. Raimondi L, D'Asaro M, Proia P, Nastasi T, Di Liegro I. RNA-binding ability of PIPPin requires the entire protein. J Cell Mol Med. 2003;7(1):35-42.

29. Bono E, Compagno V, Proia P, Raimondi L, Schiera G, Favaloro V, Campo V, Donatelli M, Di Liegro I. Thyroid hormones induce sumoylation of the cold shock domain-containing protein PIPPin in developing rat brain and in cultured neurons. Endocrinology. 2007; 148(1):252-7.

30. Di Liegro CM, Schiera G, Proia P, Saladino P, Di Liegro I. Identification in the rat brain of a set of nuclear proteins interacting with $\mathrm{H} 1$ degrees mRNA. Neuroscience. 2013;229:71-6.

31. Anderson EC, Catnaigh PO. Regulation of the expression and activity of Unr in mammalian cells. Biochem Soc Trans. 2015;43(6):1241-6.

32. Ray S, Catnaigh PO, Anderson EC. Post-transcriptional regulation of gene expression by Unr. Biochem Soc Trans. 2015;43(3):323-7.

33. Jeffers M, Paciucci R, Pellicer A. Characterization of unr; a gene closely linked to N-ras. Nucleic Acids Res. 1990;18(16):4891-9.

34. Jeffers $M$, Pellicer A. Multiple intragenic elements regulate the expression of the murine $\mathrm{N}$-ras gene. Oncogene. 1992;7(11):2115-23.

35. Jacquemin-Sablon H, Dautry F. Organization of the unr/N-ras locus: characterization of the promoter region of the human unr gene. Nucleic Acids Res. 1992;20(23):6355-61.

36. Boussadia $\mathrm{O}$, Amiot $F$, Cases $\mathrm{S}$, Triqueneaux $\mathrm{G}$, Jacquemin-Sablon $\mathrm{H}$, Dautry F. Transcription of unr (upstream of $\mathrm{N}$-ras) down-modulates $\mathrm{N}$-ras expression in vivo. FEBS Lett. 1997;420(1):20-4.

37. Jacquemin-Sablon H, Triqueneaux G, Deschamps S, le Maire M, Doniger J, Dautry F. Nucleic acid binding and intracellular localization of unr, a protein with five cold shock domains. Nucleic Acids Res. 1994;22(13):2643-50.

38. Doniger J, Landsman D, Gonda MA, Wistow G. The product of unr, the highly conserved gene upstream of $\mathrm{N}$-ras, contains multiple repeats similar to the cold-shock domain (CSD), a putative DNA-binding motif. New Biol. 1992;4(4):389-95.

39. Boussadia O, Jacquemin-Sablon H, Dautry F. Exon skipping in the expression of the gene immediately upstream of $\mathrm{N}$-ras (unr/NRU). Biochim Biophys Acta. 1993;1172(1-2):64-72.

40. Ferrer N, Garcia-Espana A, Jeffers M, Pellicer A. The unr gene: evolutionary considerations and nucleic acid-binding properties of its long isoform product. DNA Cell Biol. 1999;18(3):209-18.
41. Triqueneaux G, Velten M, Franzon P, Dautry F, Jacquemin-Sablon H. RNA binding specificity of Unr, a protein with five cold shock domains. Nucleic Acids Res. 1999;27(8):1926-34.

42. Mitchell SA, Brown EC, Coldwell MJ, Jackson RJ, Willis AE. Protein factor requirements of the Apaf-1 internal ribosome entry segment: roles of polypyrimidine tract binding protein and upstream of $\mathrm{N}$-ras. Mol Cell Biol. 2001;21(10):3364-74

43. Sawicka K, Bushell M, Spriggs KA, Willis AE. Polypyrimidine-tract-binding protein: a multifunctional RNA-binding protein. Biochem Soc Trans. 2008; 36(Pt 4):641-7.

44. Elatmani H, Dormoy-Raclet V, Dubus P, Dautry F, Chazaud C, JacqueminSablon $\mathrm{H}$. The RNA-binding protein Unr prevents mouse embryonic stem cells differentiation toward the primitive endoderm lineage. Stem Cells. 2011;29(10):1504-16.

45. Ju Lee H, Bartsch D, Xiao C, Guerrero S, Ahuja G, Schindler C, Moresco JJ, Yates JR 3rd, Gebauer F, Bazzi H, Dieterich C, Kurian L, Vilchez D. A posttranscriptional program coordinated by CSDE1 prevents intrinsic neural differentiation of human embryonic stem cells. Nat Commun. 2017;8(1):1456.

46. Markmiller S, Soltanieh S, Server KL, Mak R, Jin W, Fang MY, Luo EC, Krach F, Yang D, Sen A, Fulzele A, Wozniak JM, Gonzalez DJ, Kankel MW, Gao FB, Bennett EJ, et al. Context-dependent and disease-specific diversity in protein interactions within stress granules. Cell. 2018;172(3):590-604 e513.

47. Youn JY, Dunham WH, Hong SJ, Knight JDR, Bashkurov M, Chen Gl, Bagci H, Rathod B, MacLeod G, Eng SWM, Angers S, Morris Q, Fabian M, Cote JF, Gingras AC. High-density proximity mapping reveals the subcellular organization of mRNA-associated granules and bodies. Mol Cell. 2018;69(3): 517-32 e511.

48. Hou H, Wang F, Zhang W, Wang D, Li X, Bartlam M, Yao X, Rao Z. Structurefunctional analyses of CRHSP-24 plasticity and dynamics in oxidative stress response. J Biol Chem. 2011;286(11):9623-35.

49. Mahboubi H, Stochaj U. Cytoplasmic stress granules: dynamic modulators of cell signaling and disease. Biochim Biophys Acta. 2017;1863(4):884-95.

50. Gulow K, Bienert D, Haas IG. BiP is feed-back regulated by control of protein translation efficiency. J Cell Sci. 2002;115(Pt 11):2443-52.

51. Kang S, Lee TA, Ra EA, Lee E, Choi H, Lee S, Park B. Differential control of interleukin-6 mRNA levels by cellular distribution of YB-1. PLoS One. 2014; 9(11):e112754.

52. Kossinova OA, Gopanenko AV, Tamkovich SN, Krasheninina OA, Tupikin AE, Kiseleva E, Yanshina DD, Malygin AA, Ven'yaminova AG, Kabilov MR, Karpova GG. Cytosolic YB-1 and NSUN2 are the only proteins recognizing specific motifs present in mRNAs enriched in exosomes. Biochim Biophys Acta. 2017;1865(6):664-73.

53. Castellana B, Aasen T, Moreno-Bueno G, Dunn SE, Ramon y Cajal S. Interplay between YB-1 and IL-6 promotes the metastatic phenotype in breast cancer cells. Oncotarget. 2015;6(35):38239-56.

54. Raffetseder U, Rauen T, Boor P, Ostendorf T, Hanssen L, Floege J, En-Nia A, Djudjaj S, Frye BC, Mertens PR. Extracellular YB-1 blockade in experimental nephritis upregulates Notch-3 receptor expression and signaling. Nephron Exp Nephrol. 2011:118(4):e100-8.

55. Fukada T, Tonks NK. Identification of YB-1 as a regulator of PTP1B expression: implications for regulation of insulin and cytokine signaling. EMBO J. 2003;22(3):479-93.

56. Sorokin AV, Selyutina AA, Skabkin MA, Guryanov SG, Nazimov IV, Richard C, Th'ng J, Yau J, Sorensen PH, Ovchinnikov LP, Evdokimova V. Proteasomemediated cleavage of the Y-box-binding protein 1 is linked to DNA-damage stress response. EMBO J. 2005;24(20):3602-12.

57. Blenkiron C, Hurley DG, Fitzgerald S, Print CG, Lasham A. Links between the oncoprotein YB-1 and small non-coding RNAs in breast cancer. PLoS One. 2013;8(11):e80171.

58. Dong W, Wang H, Shahzad K, Bock F, Al-Dabet MM, Ranjan S, Wolter J, Kohli S, Hoffmann J, Dhople VM, Zhu C, Lindquist JA, Esmon CT, Grone E, Grone HJ, Madhusudhan T, et al. Activated protein C ameliorates renal ischemia-reperfusion injury by restricting Y-box binding Protein-1 ubiquitination. J Am Soc Nephrol. 2015;26(11):2789-99.

59. Kedersha N, Stoecklin G, Ayodele M, Yacono P, Lykke-Andersen J, Fritzler MJ, Scheuner D, Kaufman RJ, Golan DE, Anderson P. Stress granules and processing bodies are dynamically linked sites of mRNP remodeling. J Cell Biol. 2005;169(6):871-84.

60. Teixeira D, Sheth U, Valencia-Sanchez MA, Brengues M, Parker R. Processing bodies require RNA for assembly and contain nontranslating mRNAs. RNA. 2005;11(4):371-82 
61. Tourriere H, Chebli K, Zekri L, Courselaud B, Blanchard JM, Bertrand E, Tazi J. The RasGAP-associated endoribonuclease G3BP assembles stress granules. J Cell Biol. 2003;160(6):823-31.

62. Anderson P, Kedersha N, Ivanov P. Stress granules, P-bodies and cancer. Biochim Biophys Acta. 2015;1849(7):861-70.

63. Van Treeck B, Protter DSW, Matheny T, Khong A, Link CD, Parker R. RNA selfassembly contributes to stress granule formation and defining the stress granule transcriptome. Proc Natl Acad Sci U S A. 2018;115(11):2734-9.

64. Protter DS, Parker R. Principles and properties of stress granules. Trends Cell Biol. 2016;26(9):668-79.

65. Bounedjah O, Desforges B, Wu TD, Pioche-Durieu C, Marco S, Hamon L, Curmi PA, Guerquin-Kern JL, Pietrement $O$, Pastre D. Free mRNA in excess upon polysome dissociation is a scaffold for protein multimerization to form stress granules. Nucleic Acids Res. 2014;42(13):8678-91.

66. Maharana S, Wang J, Papadopoulos DK, Richter D, Pozniakovsky A, Poser I, Bickle M, Rizk S, Guillen-Boixet J, Franzmann TM, Jahnel M, Marrone L, Chang YT, Sterneckert J, Tomancak P, Hyman AA, et al. RNA buffers the phase separation behavior of prion-like RNA binding proteins. Science. 2018; 360(6391):918-21.

67. Kato M, Han TW, Xie S, Shi K, Du X, Wu LC, Mirzaei H, Goldsmith EJ, Longgood J, Pei J, Grishin NV, Frantz DE, Schneider JW, Chen S, Li L, Sawaya $M R$, et al. Cell-free formation of RNA granules: low complexity sequence domains form dynamic fibers within hydrogels. Cell. 2012;149(4):753-67.

68. Han TW, Kato M, Xie S, Wu LC, Mirzaei H, Pei J, Chen M, Xie Y, Allen J, Xiao G, McKnight SL. Cell-free formation of RNA granules: bound RNAs identify features and components of cellular assemblies. Cell. 2012;149(4):768-79.

69. Lagier-Tourenne C, Polymenidou M, Cleveland DW. TDP-43 and FUS/TLS emerging roles in RNA processing and neurodegeneration. Hum Mol Genet. 2010;19(R1):R46-64.

70. Ito D, Hatano M, Suzuki N. RNA binding proteins and the pathological cascade in ALS/FTD neurodegeneration. Sci Transl Med. 2017;9(415). https:// doi.org/10.1126/scitranslmed.aah5436.

71. Maziuk B, Ballance HI, Wolozin B. Dysregulation of RNA binding protein aggregation in neurodegenerative disorders. Front Mol Neurosci. 2017;10:89.

72. Buchan JR, Kolaitis RM, Taylor JP, Parker R. Eukaryotic stress granules are cleared by autophagy and Cdc48/NCP function. Cell. 2013;153(7):1461-74.

73. Shi Y, Lin S, Staats KA, Li Y, Chang WH, Hung ST, Hendricks E, Linares GR, Wang Y, Son EY, Wen X, Kisler K, Wilkinson B, Menendez L, Sugawara T, Woolwine P, et al. Haploinsufficiency leads to neurodegeneration in C9ORF72 ALS/FTD human induced motor neurons. Nat Med. 2018;24(3):313-25.

74. Ivanov P, O'Day E, Emara MM, Wagner G, Lieberman J, Anderson P. Gquadruplex structures contribute to the neuroprotective effects of angiogenin-induced tRNA fragments. Proc Natl Acad Sci U S A. 2014; 111(51):18201-6.

75. Kedersha N, Anderson P. Mammalian stress granules and processing bodies. Methods Enzymol. 2007:431:61-81.

76. Guryanov SG, Filimonov W, Timchenko AA, Melnik BS, Kihara H, Kutyshenko VP, Ovchinnikov LP, Semisotnov GV. The major mRNP protein YB-1: structural and association properties in solution. Biochim Biophys Acta. 2013;1834(2):559-67

77. Selivanova OM, Guryanov SG, Enin GA, Skabkin MA, Ovchinnikov LP, Serdyuk IN. YB-1 is capable of forming extended nanofibrils. Biochemistry (Mosc). 2010;75(1):115-20.

78. Guryanov SG, Selivanova OM, Nikulin AD, Enin GA, Melnik BS, Kretov DA, Serdyuk IN, Ovchinnikov LP. Formation of amyloid-like fibrils by Y-box binding protein 1 (YB-1) is mediated by its cold shock domain and modulated by disordered terminal domains. PLoS One. 2012;7(5):e36969.

79. Kretov DA, Curmi PA, Hamon L, Abrakhi S, Desforges B, Ovchinnikov LP, Pastre D. mRNA and DNA selection via protein multimerization: YB-1 as a case study. Nucleic Acids Res. 2015;43(19):9457-73.

80. Skabkin MA, Kiselyova OI, Chernov KG, Sorokin AV, Dubrovin EV, Yaminsky IV, Vasiliev VD, Ovchinnikov LP. Structural organization of mRNA complexes with major core mRNP protein YB-1. Nucleic Acids Res. 2004;32(18):5621-35.

81. Kloks CP, Spronk CA, Lasonder E, Hoffmann A, Vuister GW, Grzesiek S, Hilbers CW. The solution structure and DNA-binding properties of the coldshock domain of the human Y-box protein YB-1. J Mol Biol. 2002;316(2): 317-26

82. Abrakhi S, Kretov DA, Desforges B, Dobra I, Bouhss A, Pastre D, Hamon L. Nanoscale analysis reveals the maturation of neurodegeneration-associated protein aggregates: grown in mRNA granules then released by stress granule proteins. ACS Nano. 2017;11(7):7189-200.
83. Somasekharan SP, El-Naggar A, Leprivier G, Cheng H, Hajee S, Grunewald TG, Zhang F, Ng T, Delattre O, Evdokimova V, Wang Y, Gleave M, Sorensen $\mathrm{PH}$. YB-1 regulates stress granule formation and tumor progression by translationally activating G3BP1. J Cell Biol. 2015;208(7):913-29.

84. Hofmann S, Cherkasova V, Bankhead P, Bukau B, Stoecklin G. Translation suppression promotes stress granule formation and cell survival in response to cold shock. Mol Biol Cell. 2012;23(19):3786-800.

85. Shukla S, Parker R. Hypo- and hyper-assembly diseases of RNA-protein complexes. Trends Mol Med. 2016;22(7):615-28.

86. Deretic V, Jiang S, Dupont N. Autophagy intersections with conventional and unconventional secretion in tissue development, remodeling and inflammation. Trends Cell Biol. 2012;22(8):397-406.

87. Rabouille C. Pathways of unconventional protein secretion. Trends Cell Biol. 2017;27(3):230-40

88. Frye BC, Halfter S, Djudjaj S, Muehlenberg P, Weber S, Raffetseder U, En-Nia A, Knott H, Baron JM, Dooley S, Bernhagen J, Mertens PR. Y-box protein-1 is actively secreted through a non-classical pathway and acts as an extracellular mitogen. EMBO Rep. 2009;10(7):783-9.

89. Rauen T, Raffetseder U, Frye BC, Djudjaj S, Muhlenberg PJ, Eitner F, Lendahl U, Bernhagen J, Dooley S, Mertens PR. YB-1 acts as a ligand for Notch-3 receptors and modulates receptor activation. J Biol Chem. 2009;284(39): 26928-40.

90. Palicharla VR, Maddika S. HACE1 mediated K27 ubiquitin linkage leads to YB-1 protein secretion. Cell Signal. 2015;27(12):2355-62.

91. Colombo M, Moita C, van Niel G, Kowal J, Vigneron J, Benaroch P, Manel N, Moita LF, Thery C, Raposo G. Analysis of ESCRT functions in exosome biogenesis, composition and secretion highlights the heterogeneity of extracellular vesicles. J Cell Sci. 2013;126(Pt 24):5553-65.

92. Shurtleff MJ, Temoche-Diaz MM, Karfilis KV, Ri S, Schekman R. Y-box protein 1 is required to sort microRNAs into exosomes in cells and in a cell-free reaction. elife. 2016;5. https://doi.org/10.7554/eLife.19276.

93. Suresh PS, Tsutsumi R, Venkatesh T. YBX1 at the crossroads of non-coding transcriptome, exosomal, and cytoplasmic granular signaling. Eur J Cell Biol. 2018;97(3):163-7.

94. Yanshina DD, Kossinova OA, Gopanenko AV, Krasheninina OA, Malygin AA Venyaminova AG, Karpova GG. Structural features of the interaction of the 3'-untranslated region of mRNA containing exosomal RNA-specific motifs with YB-1, a potential mediator of mRNA sorting. Biochimie. 2018;144:13443.

95. Keerthikumar S, Chisanga D, Ariyaratne D, Al Saffar H, Anand S, Zhao K Samuel M, Pathan M, Jois M, Chilamkurti N, Gangoda L, Mathivanan S. ExoCarta: a web-based compendium of Exosomal cargo. J Mol Biol. 2016; 428(4):688-92

96. Simpson RJ, Kalra H, Mathivanan S. ExoCarta as a resource for exosomal research. J Extracell Vesicles. 2012;1. https://doi.org/10.3402/jev.v1i0.18374.

97. Bergmann S, Royer-Pokora B, Fietze E, Jurchott K, Hildebrandt B, Trost D, Leenders F, Claude JC, Theuring F, Bargou R, Dietel M, Royer HD. YB-1 provokes breast cancer through the induction of chromosomal instability that emerges from mitotic failure and centrosome amplification. Cancer Res. 2005;65(10):4078-87.

98. Kosnopfel C, Sinnberg T, Schittek B. Y-box binding protein 1--a prognostic marker and target in tumour therapy. Eur J Cell Biol. 2014;93(1-2):61-70.

99. Asakuno K, Kohno K, Uchiumi T, Kubo T, Sato S, Isono M, Kuwano M. Involvement of a DNA binding protein, MDR-NF1/YB-1, in human MDR1 gene expression by actinomycin D. Biochem Biophys Res Commun. 1994; 199(3):1428-35.

100. Bargou RC, Jurchott K, Wagener C, Bergmann S, Metzner S, Bommert K, Mapara MY, Winzer KJ, Dietel M, Dorken B, Royer HD. Nuclear localization and increased levels of transcription factor $\mathrm{YB}-1$ in primary human breast cancers are associated with intrinsic MDR1 gene expression. Nat Med. 1997; 3(4):447-50

101. Chattopadhyay R, Das S, Maiti AK, Boldogh I, Xie J, Hazra TK, Kohno K, Mitra $\mathrm{S}$, Bhakat KK. Regulatory role of human AP-endonuclease (APE1/Ref-1) in YB1 -mediated activation of the multidrug resistance gene MDR1. Mol Cell Biol. 2008;28(23):7066-80

102. Kuwano M, Oda $Y$, Izumi $H$, Yang SJ, Uchiumi T, Iwamoto $Y$, Toi M, Fujii T, Yamana H, Kinoshita H, Kamura T, Tsuneyoshi M, Yasumoto K, Kohno K. The role of nuclear $Y$-box binding protein 1 as a global marker in drug resistance. Mol Cancer Ther. 2004;3(11):1485-92.

103. Janz M, Harbeck N, Dettmar P, Berger U, Schmidt A, Jurchott K, Schmitt M, Royer HD. Y-box factor YB-1 predicts drug resistance and patient outcome 
in breast cancer independent of clinically relevant tumor biologic factors HER2, UPA and PAI-1. Int J Cancer. 2002;97(3):278-82.

104. Oda Y, Ohishi Y, Saito T, Hinoshita E, Uchiumi T, Kinukawa N, Iwamoto Y, Kohno K, Kuwano M, Tsuneyoshi M. Nuclear expression of Y-box-binding protein-1 correlates with P-glycoprotein and topoisomerase II alpha expression, and with poor prognosis in synovial sarcoma. J Pathol. 2003; 199(2):251-8.

105. Shen H, Xu W, Luo W, Zhou L, Yong W, Chen F, Wu C, Chen Q, Han X. Upregulation of mdr1 gene is related to activation of the MAPK/ERK signal transduction pathway and YB-1 nuclear translocation in B-cell lymphoma. Exp Hematol. 2011;39(5):558-69.

106. Setoguchi K, Cui L, Hachisuka N, Obchoei S, Shinkai K, Hyodo F, Kato K, Wada F, Yamamoto T, Harada-Shiba M, Obika S, Nakano K. Antisense oligonucleotides targeting Y-box binding Protein-1 inhibit tumor angiogenesis by downregulating BCl-xL-VEGFR2/-tie axes. Mol Ther Nucleic Acids. 2017;9:170-81.

107. di Martino O, Troiano A, Guarino AM, Pollice A, Vivo M, La Mantia G, Calabro V. DeltaNp63alpha controls YB-1 protein stability: evidence on YB-1 as a new player in keratinocyte differentiation. Genes Cells. 2016;21(6):648-60.

108. Chibi M, Meyer M, Skepu A, DJ GR, Moolman-Smook JC, Pugh DJ. RBBP6 interacts with multifunctional protein YB-1 through its RING finger domain, leading to ubiquitination and proteosomal degradation of YB-1. J Mol Biol. 2008;384(4):908-16.

109. van Roeyen CR, Scurt FG, Brandt S, Kuhl VA, Martinkus S, Djudjaj S, Raffetseder U, Royer HD, Stefanidis I, Dunn SE, Dooley S, Weng H, Fischer T, Lindquist JA, Mertens PR. Cold shock Y-box protein-1 proteolysis autoregulates its transcriptional activities. Cell Commun Signal. 2013;11:63.

110. Kim ER, Selyutina AA, Buldakov IA, Evdokimova V, Ovchinnikov LP, Sorokin $A V$. The proteolytic YB-1 fragment interacts with DNA repair machinery and enhances survival during DNA damaging stress. Cell Cycle. 2013;12(24): 3791-803.

111. Stenina OI, Poptic EJ, Di Corleto PE. Thrombin activates a Y box-binding protein (DNA-binding protein B) in endothelial cells. J Clin Invest. 2000; 106(4):579-87.

112. Tacke F, Kanig N, En-Nia A, Kaehne T, Eberhardt CS, Shpacovitch V, Trautwein C, Mertens PR. Y-box protein-1/p18 fragment identifies malignancies in patients with chronic liver disease. BMC Cancer. 2011;11:185.

113. Tacke F, Galm O, Kanig N, Yagmur E, Brandt S, Lindquist JA, Eberhardt CS, Raffetseder U, Mertens PR. High prevalence of Y-box protein-1/p18 fragment in plasma of patients with malignancies of different origin. BMC Cancer. 2014;14:33.

114. Rohr I, Braicu El, En-Nia A, Heinrich M, Richter R, Chekerov R, Dechend R, Heidecke H, Dragun D, Schafer R, Gorny X, Lindquist JA, Brandt S, Sehouli J, Mertens PR. Y-box protein-1/p18 as novel serum marker for ovarian cancer diagnosis: a study by the tumor Bank ovarian Cancer (TOC). Cytokine. 2016; 85:157-64.

115. Ferreira AR, Bettencourt M, Alho I, Costa AL, Sousa AR, Mansinho A, Abreu C, Pulido C, Macedo D, Vendrell I, Pacheco TR, Costa L, Casimiro S. Serum YB-1 (Y-box binding protein 1) as a biomarker of bone disease progression in patients with breast cancer and bone metastases. J Bone Oncol. 2017;6: 16-21.

116. Jiang S, Baltimore D. RNA-binding protein Lin28 in cancer and immunity. Cancer Lett. 2016;375(1):108-13.

117. Evans JR, Mitchell SA, Spriggs KA, Ostrowski J, Bomsztyk K, Ostarek D, Willis $\mathrm{AE}$. Members of the poly ( $\mathrm{rC}$ ) binding protein family stimulate the activity of the c-myc internal ribosome entry segment in vitro and in vivo. Oncogene. 2003;22(39):8012-20.

118. Grosset C, Chen CY, Xu N, Sonenberg N, Jacquemin-Sablon H, Shyu AB. A mechanism for translationally coupled mRNA turnover: interaction between the poly(a) tail and a c-fos RNA coding determinant via a protein complex. Cell. 2000;103(1):29-40.

119. Wurth L, Papasaikas P, Olmeda D, Bley N, Calvo GT, Guerrero S, CerezoWallis D, Martinez-Useros J, Garcia-Fernandez M, Huttelmaier S, Soengas MS, Gebauer F. UNR/CSDE1 drives a post-transcriptional program to promote melanoma invasion and metastasis. Cancer Cell. 2016;30(5):694-707.

120. Wu Q, Parry G. Hepsin and prostate cancer. Front Biosci. 2007;12:5052-9.

121. Zhang C, Zhang M, Wu Q, Peng J, Ruan Y, Gu J. Hepsin inhibits CDK11p58 IRES activity by suppressing unr expression and elF-2alpha phosphorylation in prostate cancer. Cell Signal. 2015;27(4):789-97.

122. Martinez-Useros J, Georgiev-Hristov T, Fernandez-Acenero MJ, BorreroPalacios A, Indacochea A, Guerrero S, Li W, Cebrian A, Gomez Del Pulgar T,
Puime-Otin A, Del Puerto-Nevado L, Rodriguez-Remirez M, Perez N, Celdran A, Gebauer F, Garcia-Foncillas J. UNR/CDSE1 expression as prognosis biomarker in resectable pancreatic ductal adenocarcinoma patients: a proofof-concept. PLoS One. 2017;12(8):e0182044.

123. Hanssen L, Alidousty C, Djudjaj S, Frye BC, Rauen T, Boor P, Mertens PR, van Roeyen CR, Tacke F, Heymann F, Tittel AP, Koch A, Floege J, Ostendorf T, Raffetseder U. YB-1 is an early and central mediator of bacterial and sterile inflammation in vivo. J Immunol. 2013;191(5):2604-13.

124. Wang J, Gibbert L, Djudjaj S, Alidousty C, Rauen T, Kunter U, Rembiak A, Enders D, Jankowski V, Braun GS, Floege J, Ostendorf T, Raffetseder U. Therapeutic nuclear shuttling of YB-1 reduces renal damage and fibrosis. Kidney Int. 2016;90(6):1226-37.

125. Alidousty C, Rauen T, Hanssen L, Wang Q, Alampour-Rajabi S, Mertens PR, Bernhagen J, Floege J, Ostendorf T, Raffetseder U. Calcineurin-mediated YB1 dephosphorylation regulates CCL5 expression during monocyte differentiation. J Biol Chem. 2014;289(31):21401-12.

126. Raffetseder U, Rauen T, Djudjaj S, Kretzler M, En-Nia A, Tacke F, Zimmermann HW, Nelson PJ, Frye BC, Floege J, Stefanidis I, Weber C, Mertens PR. Differential regulation of chemokine CCL5 expression in monocytes/macrophages and renal cells by Y-box protein-1. Kidney Int. 2009;75(2):185-96.

127. Krohn R, Raffetseder U, Bot I, Zernecke A, Shagdarsuren E, Liehn EA, van Santbrink PJ, Nelson PJ, Biessen EA, Mertens PR, Weber C. Y-box binding protein-1 controls CC chemokine ligand-5 (CCL5) expression in smooth muscle cells and contributes to neointima formation in atherosclerosisprone mice. Circulation. 2007;116(16):1812-20.

128. Dhawan L, Liu B, Pytlak A, Kulshrestha S, Blaxall BC, Taubman MB. Y-box binding protein 1 and RNase UK114 mediate monocyte chemoattractant protein 1 mRNA stability in vascular smooth muscle cells. Mol Cell Biol. 2012:32(18):3768-75.

129. Chen CY, Gherzi R, Andersen JS, Gaietta G, Jurchott K, Royer HD, Mann M, Karin M. Nucleolin and YB-1 are required for JNK-mediated interleukin-2 mRNA stabilization during T-cell activation. Genes Dev. 2000;14(10):1236-48.

130. Coles LS, Diamond P, Lambrusco L, Hunter J, Burrows J, Vadas MA, Goodall GJ. A novel mechanism of repression of the vascular endothelial growth factor promoter, by single strand DNA binding cold shock domain (Y-box) proteins in normoxic fibroblasts. Nucleic Acids Res. 2002;30(22):4845-54.

131. Diamond P, Shannon MF, Vadas MA, Coles LS. Cold shock domain factors activate the granulocyte-macrophage colony-stimulating factor promoter in stimulated Jurkat T cells. J Biol Chem. 2001;276(11):7943-51.

132. Fraser DJ, Phillips AO, Zhang X, van Roeyen CR, Muehlenberg P, En-Nia A, Mertens PR. Y-box protein-1 controls transforming growth factor-beta1 translation in proximal tubular cells. Kidney Int. 2008;73(6):724-32.

133. Berquin IM, Pang B, Dziubinski ML, Scott LM, Chen YQ, Nolan GP, Ethier SP. Y-box-binding protein 1 confers EGF independence to human mammary epithelial cells. Oncogene. 2005;24(19):3177-86.

134. Basaki Y, Hosoi F, Oda Y, Fotovati A, Maruyama Y, Oie S, Ono M, Izumi H, Kohno K, Sakai K, Shimoyama T, Nishio K, Kuwano M. Akt-dependent nuclear localization of Y-box-binding protein 1 in acquisition of malignant characteristics by human ovarian cancer cells. Oncogene. 2007;26(19):2736-46.

135. Mertens PR, Harendza S, Pollock AS, Lovett DH. Glomerular mesangial cellspecific transactivation of matrix metalloproteinase 2 transcription is mediated by YB-1. J Biol Chem. 1997;272(36):22905-12.

136. Hanssen L, Frye BC, Ostendorf T, Alidousty C, Djudjaj S, Boor P, Rauen T, Floege J, Mertens PR, Raffetseder U. Y-box binding protein-1 mediates profibrotic effects of calcineurin inhibitors in the kidney. J Immunol. 2011; 187(1):298-308.

137. Higashi K, Inagaki Y, Suzuki N, Mitsui S, Mauviel A, Kaneko H, Nakatsuka I. Ybox-binding protein YB-1 mediates transcriptional repression of human alpha 2(I) collagen gene expression by interferon-gamma. J Biol Chem. 2003;278(7):5156-62

138. van Roeyen CR, Eitner F, Martinkus S, Thieltges SR, Ostendorf T, Bokemeyer D, Luscher B, Luscher-Firzlaff JM, Floege J, Mertens PR. Y-box protein 1 mediates PDGF-B effects in mesangioproliferative glomerular disease. J Am Soc Nephrol. 2005;16(10):2985-96.

139. Raffetseder U, Liehn EA, Weber C, Mertens PR. Role of cold shock Y-box protein-1 in inflammation, atherosclerosis and organ transplant rejection. Eur J Cell Biol. 2012:91(6-7):567-75.

140. Capowski EE, Esnault S, Bhattacharya S, Malter JS. Y box-binding factor promotes eosinophil survival by stabilizing granulocyte-macrophage colonystimulating factor mRNA. J Immunol. 2001;167(10):5970-6. 
141. Esnault S, Malter JS. Hyaluronic acid or TNF-alpha plus fibronectin triggers granulocyte macrophage-colony-stimulating factor mRNA stabilization in eosinophils yet engages differential intracellular pathways and mRNA binding proteins. J Immunol. 2003;171(12):6780-7.

142. Higashi K, Tomigahara Y, Shiraki H, Miyata K, Mikami T, Kimura T, Moro T, Inagaki $Y$, Kaneko H. A novel small compound that promotes nuclear translocation of YB-1 ameliorates experimental hepatic fibrosis in mice. J Biol Chem. 2011;286(6):4485-92.

143. Imai J, Hozumi K, Sumiyoshi H, Yazawa M, Hirano K, Abe J, Higashi K, Inagaki $Y$, Mine T. Anti-fibrotic effects of a novel small compound on the regulation of cytokine production in a mouse model of colorectal fibrosis. Biochem Biophys Res Commun. 2015;468(4):554-60

144. Khan Ml, Adhami VM, Lall RK, Sechi M, Joshi DC, Haidar OM, Syed DN, Siddiqui IA, Chiu SY, Mukhtar H. YB-1 expression promotes epithelial-tomesenchymal transition in prostate cancer that is inhibited by a small molecule fisetin. Oncotarget. 2014;5(9):2462-74.

145. Gunasekaran VP, Nishi K, Sivakumar D, Sivaraman T, Mathan G. Identification of 2,4-dihydroxy-5-pyrimidinyl imidothiocarbomate as a novel inhibitor to $Y$ box binding protein-1 (YB-1) and its therapeutic actions against breast cancer. Eur J Pharm Sci. 2018;116:2-14.

146. Ciani F, Tafuri S, Troiano A, Cimmino A, Fioretto BS, Guarino AM, Pollice A Vivo M, Evidente A, Carotenuto D, Calabro V. Anti-proliferative and proapoptotic effects of Uncaria tomentosa aqueous extract in squamous carcinoma cells. J Ethnopharmacol. 2018;211:285-94.

147. Prabhu L, Mundade R, Wang B, Wei H, Hartley AV, Martin M, McElyea K, Temm CJ, Sandusky G, Liu Y, Lu T. Critical role of phosphorylation of serine 165 of YBX1 on the activation of NF-kappaB in colon cancer. Oncotarget. 2015;6(30):29396-412.

148. Martin M, Hua L, Wang B, Wei H, Prabhu L, Hartley AV, Jiang G, Liu Y, Lu T. Novel serine 176 phosphorylation of YBX1 activates NF-kappaB in colon cancer. J Biol Chem. 2017;292(8):3433-444.

149. Inoue K, Fry EA, Frazier DP. Transcription factors that interact with p53 and Mdm2. Int J Cancer. 2016;138(7):1577-85.

150. Homer C, Knight DA, Hananeia L, Sheard P, Risk J, Lasham A, Royds JA, Braithwaite AW. Y-box factor YB1 controls p53 apoptotic function. Oncogene. 2005;24(56):8314-25.

151. Okamoto T, Izumi H, Imamura T, Takano H, Ise T, Uchiumi T, Kuwano M, Kohno K. Direct interaction of p53 with the Y-box binding protein, YB-1: a mechanism for regulation of human gene expression. Oncogene. 2000; 19(54):6194-202

152. Kato M, Wang L, Putta S, Wang M, Yuan H, Sun G, Lanting L, Todorov I, Rossi JJ, Natarajan R. Post-transcriptional up-regulation of Tsc-22 by Ybx1, a target of miR-216a, mediates TGF-\{beta\}-induced collagen expression in kidney cells. J Biol Chem. 2010;285(44):34004-15.

153. Dooley S, Said HM, Gressner AM, Floege J, En-Nia A, Mertens PR. Y-box protein-1 is the crucial mediator of antifibrotic interferon-gamma effects. J Biol Chem. 2006;281(3):1784-95.

154. Zhang Q, Lenardo MJ, Baltimore D. 30 years of NF-kappaB: a blossoming of relevance to human pathobiology. Cell. 2017;168(1-2):37-57.

155. Basak S, Behar M, Hoffmann A. Lessons from mathematically modeling the NF-kappaB pathway. Immunol Rev. 2012;246(1):221-38.

156. Hayden MS, Ghosh S. Regulation of NF-kappaB by TNF family cytokines. Semin Immunol. 2014;26(3):253-66.

157. Maubach G, Schmadicke AC, Naumann M. NEMO links nuclear factorkappaB to human diseases. Trends Mol Med. 2017;23(12):1138-55.

158. Abbas AK, Trotta E, RS D, Marson A, Bluestone JA. Revisiting IL-2: biology and therapeutic prospects. Sci Immunol. 2018;3(25). https://doi.org/10.1126/ sciimmunol.aat1482.

159. Malek TR, Yu A, Zhu L, Matsutani T, Adeegbe D, Bayer AL. IL-2 family of cytokines in $T$ regulatory cell development and homeostasis. J Clin Immunol. 2008;28(6):635-9.

160. Boyman O, Sprent J. The role of interleukin-2 during homeostasis and activation of the immune system. Nat Rev Immunol. 2012;12(3):180-90.

161. Malek TR. The biology of interleukin-2. Annu Rev Immunol. 2008;26:453-79.

162. Braithwaite AW, Del Sal G, Lu X. Some p53-binding proteins that can function as arbiters of life and death. Cell Death Differ. 2006;13(6):984-93.

163. Meek DW. Regulation of the p53 response and its relationship to cancer. Biochem J. 2015;469(3):325-46.

164. Vogelstein B, Lane D, Levine AJ. Surfing the p53 network. Nature. 2000; 408(6810):307-10.

165. Charni M, Aloni-Grinstein R, Molchadsky A, Rotter V. p53 on the crossroad between regeneration and cancer. Cell Death Differ. 2017;24(1):8-14.
166. Duffy MJ, Synnott NC, McGowan PM, Crown J, O'Connor D, Gallagher WM. p53 as a target for the treatment of cancer. Cancer Treat Rev. 2014;40(10): 1153-60.

167. Loeffler I, Wolf G. Transforming growth factor-beta and the progression of renal disease. Nephrol Dial Transplant. 2014;29(Suppl 1):i37-45.

168. Yingling JM, Blanchard KL, Sawyer JS. Development of TGF-beta signalling inhibitors for cancer therapy. Nat Rev Drug Discov. 2004;3(12):1011-22.

169. Wallace $E$, Gewin L. Imatinib: novel treatment of immune-mediated kidney injury. J Am Soc Nephrol. 2013;24(5):694-701.

170. Gordon J, Spiera R. Imatinib and the treatment of fibrosis: recent trials and tribulations. Curr Rheumatol Rep. 2011;13(1):51-8.

171. Brandt S, Mertens PR. A remedy for kidney disease successfully alters the cold shock protein response during inflammation. Kidney Int. 2016;90(6): 1148-50.

172. Hasegawa M, Matsushita Y, Horikawa M, Higashi K, Tomigahara Y, Kaneko H, Shirasaki F, Fujimoto M, Takehara K, Sato S. A novel inhibitor of Smaddependent transcriptional activation suppresses tissue fibrosis in mouse models of systemic sclerosis. Arthritis Rheum. 2009;60(11):3465-75.

173. Inagaki $Y$, Kushida M, Higashi K, Itoh J, Higashiyama R, Hong YY, Kawada N, Namikawa K, Kiyama H, Bou-Gharios G, Watanabe T, Okazaki I, Ikeda K. Cell type-specific intervention of transforming growth factor beta/Smad signaling suppresses collagen gene expression and hepatic fibrosis in mice. Gastroenterology. 2005;129(1):259-68.

174. Higashi K, Inagaki Y, Fujimori K, Nakao A, Kaneko H, Nakatsuka I. Interferongamma interferes with transforming growth factor-beta signaling through direct interaction of YB-1 with Smad3. J Biol Chem. 2003;278(44):43470-9.

175. Norman JT, Lindahl GE, Shakib K, En-Nia A, Yilmaz E, Mertens PR. The Y-box binding protein YB-1 suppresses collagen alpha 1(I) gene transcription via an evolutionarily conserved regulatory element in the proximal promoter. J Biol Chem. 2001;276(32):29880-90.

176. Syed DN, Adhami VM, Khan MI, Mukhtar H. Inhibition of Akt/mTOR signaling by the dietary flavonoid fisetin. Anti Cancer Agents Med Chem. 2013;13(7): 995-1001.

177. Gupta SC, Tyagi AK, Deshmukh-Taskar P, Hinojosa M, Prasad S, Aggarwal BB. Downregulation of tumor necrosis factor and other proinflammatory biomarkers by polyphenols. Arch Biochem Biophys. 2014:559:91-9.

178. Adhami VM, Syed DN, Khan N, Mukhtar H. Dietary flavonoid fisetin: a novel dual inhibitor of PI3K/Akt and mTOR for prostate cancer management. Biochem Pharmacol. 2012;84(10):1277-81.

179. Syed DN, Chamcheu JC, Khan MI, Sechi M, Lall RK, Adhami VM, Mukhtar H. Fisetin inhibits human melanoma cell growth through direct binding to p70S6K and mTOR: findings from 3-D melanoma skin equivalents and computational modeling. Biochem Pharmacol. 2014;89(3):349-60.

180. Sutherland BW, Kucab J, Wu J, Lee C, Cheang MC, Yorida E, Turbin D, Dedhar S, Nelson C, Pollak M, Leighton Grimes H, Miller K, Badve S, Huntsman D, Blake-Gilks C, Chen M, et al. Akt phosphorylates the Y-box binding protein 1 at Ser102 located in the cold shock domain and affects the anchorage-independent growth of breast cancer cells. Oncogene. 2005; 24(26):4281-92.

181. Gieseler-Halbach S, Meltendorf S, Pierau M, Weinert S, Heidel FH, Fischer T, Handschuh J, Braun-Dullaeus RC, Schrappe M, Lindquist JA, Mertens PR, Thomas U, Brunner-Weinzierl MC. RSK-mediated nuclear accumulation of the cold-shock Y-box protein-1 controls proliferation of T cells and T-ALL blasts. Cell Death Differ. 2017;24(2):371-83.

182. Li X, Kong D, Chen H, Liu S, Hu H, Wu T, Wang J, Chen W, Ning Y, Li Y, Lu Z miR-155 acts as an anti-inflammatory factor in atherosclerosis-associated foam cell formation by repressing calcium-regulated heat stable protein 1 . Sci Rep. 2016;6:21789.

183. Kalliolias GD, Ivashkiv LB. TNF biology, pathogenic mechanisms and emerging therapeutic strategies. Nat Rev Rheumatol. 2016;12(1):49-62.

184. Sollazzo D, Forte D, Polverelli N, Romano M, Perricone M, Rossi L, Ottaviani E, Luatti S, Martinelli G, Vianelli N, Cavo M, Palandri F, Catani L. Crucial factors of the inflammatory microenvironment (IL-1beta/TNF-alpha/TIMP-1) promote the maintenance of the malignant hemopoietic clone of myelofibrosis: an in vitro study. Oncotarget. 2016;7(28):43974-88.

185. Altmann C, Vasic V, Hardt S, Heidler J, Haussler A, Wittig I, Schmidt MH, Tegeder I. Progranulin promotes peripheral nerve regeneration and reinnervation: role of notch signaling. Mol Neurodegener. 2016;11(1):69.

186. Musso G, Cassader M, Cohney S, Pinach S, Saba F, Gambino R. Emerging liver-kidney interactions in nonalcoholic fatty liver disease. Trends Mol Med. 2015;21(10):645-62. 
187. Sun YY, Li XF, Meng XM, Huang C, Zhang L, Li J. Macrophage phenotype in liver injury and repair. Scand J Immunol. 2017;85(3):166-74.

188. Zhou Z, Xu MJ, Gao B. Hepatocytes: a key cell type for innate immunity. Cell Mol Immunol. 2016;13(3):301-15.

189. Lindquist JA, Schneider A, Mertens PR. Regulation of endogenous brakes to kidney fibrosis: turning the view upside down. J Mol Med (Berl). 2017;95(6): 571-3.

190. Quek C, Hill AF. The role of extracellular vesicles in neurodegenerative diseases. Biochem Biophys Res Commun. 2017:483(4):1178-86.

191. Howitt J, Hill AF. Exosomes in the pathology of neurodegenerative diseases. J Biol Chem. 2016;291(52):26589-97.

192. Vilette D, Courte J, Peyrin JM, Coudert L, Schaeffer L, Andreoletti O, Leblanc P. Cellular mechanisms responsible for cell-to-cell spreading of prions. Cell Mol Life Sci. 2018;75(14):2575.

193. Bloch DB, Nobre RA, Yang WH. GW/P-bodies and autoimmune disease. Adv Exp Med Biol. 2013;768:61-70.

194. Yang WH, Bloch DB. Probing the mRNA processing body using protein macroarrays and "autoantigenomics". RNA. 2007;13(5):704-12.

195. Jeoung DI, Bong Lee E, Lee S, Lim Y, Lee DY, Kim J, Kim HY, Wook Song Y. Autoantibody to DNA binding protein $B$ as a novel serologic marker in systemic sclerosis. Biochem Biophys Res Commun. 2002;299(4):549-54.

196. Braunschweig D, Krakowiak P, Duncanson P, Boyce R, Hansen RL, Ashwood P, Hertz-Picciotto I, Pessah IN, Van de Water J. Autism-specific maternal autoantibodies recognize critical proteins in developing brain. Transl Psychiatry. 2013;3:e277

197. Chernov KG, Curmi PA, Hamon L, Mechulam A, Ovchinnikov LP, Pastre D. Atomic force microscopy reveals binding of mRNA to microtubules mediated by two major mRNP proteins YB-1 and PABP. FEBS Lett. 2008; 582(19):2875-81.

198. Hornbeck PV, Zhang B, Murray B, Kornhauser JM, Latham V, Skrzypek E. PhosphoSitePlus, 2014: mutations, PTMs and recalibrations. Nucleic Acids Res. 2015:43(Database issue):D512-20.

199. Liu Q, Tao T, Liu F, Ni R, Lu C, Shen A. Hyper-O-GlcNAcylation of YB-1 affects Ser102 phosphorylation and promotes cell proliferation in hepatocellular carcinoma. Exp Cell Res. 2016;349(2):230-8.

200. Yang X, Qian K. Protein O-GlcNAcylation: emerging mechanisms and functions. Nat Rev Mol Cell Biol. 2017;18(7):452-65.

201. Xu W, Zhang X, Wu JL, Fu L, Liu K, Liu D, Chen GG, Lai PB, Wong N, Yu J. OGlcNAc transferase promotes fatty liver-associated liver cancer through inducing palmitic acid and activating endoplasmic reticulum stress. J Hepatol. 2017;67(2):310-20.

202. Allison DF, Wamsley JJ, Kumar M, Li D, Gray LG, Hart GW, Jones DR, Mayo MW. Modification of RelA by O-linked N-acetylglucosamine links glucose metabolism to NF-kappaB acetylation and transcription. Proc Natl Acad Sci U S A. 2012;109(42):16888-93.

203. Bernhardt A, Fehr A, Brandt S, Jerchel S, Ballhause TM, Philipsen L, Stolze S, Geffers R, Weng H, Fischer KD, Isermann B, Brunner-Weinzierl MC, Batra A, Siegmund B, Zhu C, Lindquist JA, et al. Inflammatory cell infiltration and resolution of kidney inflammation is orchestrated by the cold-shock protein Y-box binding protein-1. Kidney Int. 2017;92(5):1157-77.

204. Seko Y, Cole S, Kasprzak W, Shapiro BA, Ragheb JA. The role of cytokine mRNA stability in the pathogenesis of autoimmune disease. Autoimmun Rev. 2006;5(5):299-305

205. Coles LS, Diamond P, Occhiodoro F, Vadas MA, Shannon MF. Cold shock domain proteins repress transcription from the GM-CSF promoter. Nucleic Acids Res. 1996;24(12):2311-7.

206. Mertens PR, Martin IV, Frye BC, Rauen T, Strauch S, Pabst M, Geier A. Rat Mrp2 gene expression is regulated by an interleukin-1beta-stimulated biphasic response with enhanced transcription and subcellular shuttling of YB-1. Eur J Cell Biol. 2012:91(6-7):533-41.

207. Silveira CG, Krampe J, Ruhland B, Diedrich K, Hornung D, Agic A. Cold-shock domain family member $\mathrm{YB}-1$ expression in endometrium and endometriosis. Hum Reprod. 2012;27(1):173-82.

208. Hornung D, Bentzien F, Wallwiener D, Kiesel L, Taylor RN. Chemokine bioactivity of RANTES in endometriotic and normal endometrial stromal cells and peritoneal fluid. Mol Hum Reprod. 2001;7(2):163-8.

209. Jenkins RH, Bennagi R, Martin J, Phillips AO, Redman JE, Fraser DJ. A conserved stem loop motif in the 5 'untranslated region regulates transforming growth factor-beta(1) translation. PLoS One. 2010;5(8):e12283.

210. Coles LS, Lambrusco L, Burrows J, Hunter J, Diamond P, Bert AG, Vadas MA Goodall GJ. Phosphorylation of cold shock domain/Y-box proteins by ERK2 and GSK3beta and repression of the human VEGF promoter. FEBS Lett. 2005:579(24):5372-8.

211. Hayashi J, Kajino K, Umeda T, Takano S, Arakawa Y, Kudo M, Hino O. Somatic mutation and SNP in the promoter of $\mathrm{dbpA}$ and human hepatocarcinogenesis. Int J Oncol. 2002;21(4):847-50.

212. Yasen M, Kajino K, Kano S, Tobita H, Yamamoto J, Uchiumi T, Kon S, Maeda M, Obulhasim G, Arii S, Hino O. The up-regulation of Y-box binding proteins (DNA binding protein a and Y-box binding protein-1) as prognostic markers of hepatocellular carcinoma. Clin Cancer Res. 2005;11(20):7354-61.

213. Yasen M, Obulhasim G, Kajino K, Mogushi K, Mizushima H, Tanaka S, Tanaka $\mathrm{H}$, Hino O, Arii S. DNA binding protein a expression and methylation status in hepatocellular carcinoma and the adjacent tissue. Int J Oncol. 2012;40(3): 789-97.

214. Obulhasim G, Yasen M, Kajino K, Mogushi K, Tanaka S, Mizushima H, Tanaka $\mathrm{H}$, Arii S, Hino O. Up-regulation of dbpA mRNA in hepatocellular carcinoma associated with metabolic syndrome. Hepatol Int. 2013;7(1):215-25.

215. Letunic I, Bork P. 20 years of the SMART protein domain annotation resource. Nucleic Acids Res. 2018;46(D1):D493-6.

\section{Ready to submit your research? Choose BMC and benefit from:}

- fast, convenient online submission

- thorough peer review by experienced researchers in your field

- rapid publication on acceptance

- support for research data, including large and complex data types

- gold Open Access which fosters wider collaboration and increased citations

- maximum visibility for your research: over $100 \mathrm{M}$ website views per year

At $\mathrm{BMC}$, research is always in progress.

Learn more biomedcentral.com/submissions 